\title{
The Impact of the COVID-19 Pandemic on Business Expectations
}

\author{
Brent H. Meyer, Brian Prescott, and Xuguang Simon Sheng
}

\section{Working Paper 2020-17a \\ August 2020 (Revised December 2020)}

Abstract: We document and evaluate how businesses are reacting to the COVID-19 crisis through August 2020. First, on net, firms see the shock (thus far) largely as a demand rather than supply shock. A greater share of firms reports significant or severe disruption to sales activity than to supply chains. We compare these measures of disruption to their expected changes in selling prices and find that, even for firms that report supply chain disruption, they expect to lower near-term selling prices on average. We also show that firms are engaging in wage cuts and expect to trim wages further before the end of 2020. These cuts stem from firms that have been disproportionally negatively affected by the pandemic. Second, firms (like professional forecasters) have responded to the COVID-19 pandemic by lowering their one-year-ahead inflation expectations. These responses stand in stark contrast to that of household inflation expectations (as measured by the University of Michigan or the New York Fed). Indeed, firms' one-year-ahead inflation expectations fell precipitously (to a series low) following the onset of the pandemic, while household measures of inflation expectations jumped markedly. Third, despite the dramatic decline in firms' near-term inflation expectations, their longer-run inflation expectations remain reasonably stable.

JEL classification: E31, E32

Key words: business expectations, COVID-19, demand shock, inflation, pandemic, supply shock https://doi.org/10.29338/wp2020-17a

The authors are indebted to Nick Parker for his outstanding survey expertise and direction on wording questions. They also thank Patrick Higgins, an associate editor, and two anonymous referees for helpful comments. They also thank the participants at the International Institute of Forecasters virtual workshop titled "Economic Forecasting in Times of COVID-19" for their valuable comments and criticisms. They would also like to thank members of the Atlanta Fed's research department for their comments on these findings through internal briefings. The views expressed here are those of the authors and not necessarily those of the Federal Reserve Bank of Atlanta or the Federal Reserve System. Any remaining errors are the authors' responsibility.

Please address questions regarding content to Brent H. Meyer, Research Department, Federal Reserve Bank of Atlanta, 1000 Peachtree Street NE, Atlanta, GA 30309, brent.meyer@atl.frb.org; Brian Prescott, Research Department, Federal Reserve Bank of Atlanta, 1000 Peachtree Street NE, Atlanta, GA 30309, brian.prescott@atl.frb.org; or Xuguang Simon Sheng, Department of Economics, American University, 4400 Massachusetts Avenue NW, Washington, DC 20016, sheng@american.edu.

Federal Reserve Bank of Atlanta working papers, including revised versions, are available on the Atlanta Fed's website at www.frbatlanta.org. Click "Publications" and then "Working Papers." To receive e-mail notifications about new papers, use frbatlanta.org/forms/subscribe. 
"Now we see a big shock to demand, and we see core inflation dropping to 1 percent. And I do think for quite some time we're going to be struggling against disinflationary pressures rather than against inflationary pressures."

— Chair Powell. Post-FOMC Press Conference. July 29, 20201

\section{Introduction}

By mid-March, it was clear that a novel coronavirus (COVID-19) had reached the shores of the United States. State-mandated lockdowns temporarily shuttered many nonessential businesses, the U.S. government had instituted travel bans to many countries, and, among businesses still open, many saw depressed levels of sales activity. ${ }^{2}$ Indeed, economic activity as measured by real GDP contracted at an annualized rate of 5 percent in the first quarter and by an astounding 32 percent in the second quarter, marking the COVID-19 crisis as the swiftest and most severe economic shock the U.S. has experienced in modern times.

Amid supply chain disruption and alongside widespread shutdowns, production has been crimped. However, demand appears to have taken a bigger hit, as those emergency shutdowns have also left households shuttered in their homes, consumer spending has fallen dramatically, and business investment spending has dried up. Given the backdrop of low inflation since the onset of the Great Recession, the behavior of inflation expectations is of particular interest. In a recent speech, Fed Governor, Lael Brainard, noted, "With underlying inflation running below 2 percent for many years and COVID contributing to a further decline, it is important that monetary policy support inflation expectations that are consistent with inflation centered on 2 percent over time." 3

In this paper, we utilize the Federal Reserve Bank of Atlanta's Business Inflation Expectations

\footnotetext{
${ }^{1}$ https:/ / www.federalreserve.gov/mediacenter/files/FOMCpresconf20200729.pdf

${ }^{2}$ Based on a new big data index developed by Brave, Butters and Kelley (2019), Li and Sheng (2020) identify COVIDinduced recession beginning in March 2020. Indeed, high-frequency data on small firm closings and activity from HomeBase (https://joinhomebase.com/blog/real-time-covid-19-data/), as well as high-frequency data from Opportunity Insights (https:/ / tracktherecovery.org/) described in Chetty et al. (2020) point to a sharp contraction in activity beginning in mid-March.

${ }^{3}$ Lael Brainard. "Navigating Monetary Policy through the Fog of COVID." July 14, 2020. Remarks given via webcast to the NABE. https:/ / www.federalreserve.gov/newsevents/speech/brainard20200714a.htm
} 
Survey to uncover how firms are perceiving and reacting to the COVID-19 pandemic. Our analysis focuses, importantly, on how this shock has affected their inflation expectations going forward. First, we examine whether firms, en masse, see the pandemic as a supply or demand shock. Our results suggest that, while both elements of a supply shock and demand shock are present, firms, on net, view the COVID-19 pandemic as a demand shock. These findings are based on a series of quarterly and special questions that assess the level of disruption that COVID-19 has inflicted on sales activity, business operations, and supply chains; quantitative assessments of firms' sales levels relative to 'normal'; firms' expected price changes over the near-term; firms' experienced and expected wage changes; and changes in the inflation expectations from before to during the pandemic.

The literature disentangling firms' perceptions of the COVID-19 pandemic is nascent, mixed, and can be loosely grouped into two strains. The first strain-which argues that demand shocks dominate-takes a broad approach to uncovering the perceptions of firms regarding the nature of the pandemic, eliciting direct evidence of changes in firms' behavior, perceptions, and expectations. Hassan et al. (2020) analyze transcripts of quarterly earnings calls held by public firms across the globe and find concerns over a negative demand shock are nearly twice as prevalent as mentions of supply chain disruption. In a survey of small firms, Bartik et al. (2020) find respondents cited reductions in demand to a much larger degree than supply chain issues as reasons for temporary closures. And, Meyer, McCord and Waddell (2020) find that firms' most pressing concerns are overwhelmingly centered on flagging demand and declining sales revenue, with the 'health of the economy' coming in a distant second and 'supply chain concerns' registered as a much lower issue. ${ }^{4}$

The other strain of literature relies largely on inference rather than direct responses from business decision makers to conclude the pandemic as a supply shock. Brinca et al. (2020) use structural econometric methods to decompose changes in hours working into supply and demand shock contributions, finding that the supply shock contribution outweighs the demand shock con-

\footnotetext{
${ }^{4}$ Balleer et al. (2020) find strikingly similar results to our work in a survey of German firms, finding that demand shortfalls far outweigh supply issues, leading these firms to anticipate cutting prices. These results open the possibility that the COVID-19 shock hit firms located in industrialized countries in a similar way.
} 
tribution. Candia, Coibion and Gorodnichenko (2020) suggest that some firms (and most households) see the pandemic as a supply shock, coming to that view through the lens of aggregate inflation expectations. Related research by Dietrich et al. (2020), while focused on households, reach the same conclusion through survey research that elicits expectations for the COVID-19 pandemic's impact on aggregate inflation. Importantly, our results, like Hassan et al. (2020) take a more holistic and direct approach to uncovering firms' perceptions of the pandemic.

Second, consistent with a shortfall in demand, we document that the inflation expectations of businesses (like those of professional forecasters) have fallen precipitously. In fact, both firms' perceptions of current inflation and their year-ahead inflation expectations fell to an all-time low (going back to October 2011) in April, as the pandemic grew in severity. We also document that household survey measures of inflation expectations - specifically the University of Michigan's Survey of Consumers and the New York Fed's Survey of Consumer Expectations both registered sharp increases in expectations relative to the pre-COVID period. We offer evidence that suggests households are disproportionately responding to a relative price shock to grocery store items, rather than viewing the COVID-19 pandemic as a negative shock to aggregate supply.

Third, despite the magnitude of the decline in their near-term inflation perceptions and expectations, firms' longer-run expectations appear to be relatively stable. The relationship between a firm's change in 1-year ahead expectations and the change in its longer-run inflation expectations from the pre-COVID period to during the crisis appears to be modest at best. Moreover, while distribution of firms' 1-year ahead inflation expectations has shifted markedly lower, this downward shift is not evident in firms' longer-run (5-10 year ahead) inflation expectations, suggesting that firms' longer-run expectations are reasonably well-anchored.

The rest of the paper proceeds as follows. Section 2 briefly discusses the dataset. Section 3 analyzes how the COVID-19 shock affects firms' sales levels, business operations, expected price changes and wage changes. Section 4 and Section 5 focus on firms' short-run and long-run inflation expectations during the crisis. Section 6 concludes. 


\section{About the Survey}

We use the microdata and special question results from the Federal Reserve Bank of Atlanta's Business Inflation Expectations (BIE) survey. The BIE is a monthly survey of firms in the 6th Federal Reserve District (which covers most of the Southeastern United States) that has been fielded continuously since October 2011. Broadly speaking, the 6th district mirrors the US in terms of cross-industry and cross-firm size breakdowns of business activity (sales revenue and employment). By design, the panel composition of the BIE roughly reflects the makeup of the national economy at the two-digit NAICS level (See Appendix Table B.1. panels A and B). ${ }^{5}$

Of particular interest in disentangling firm's perceptions of the nature of the pandemic, is whether COVID-19 and the efforts to control the spread of the virus impacted 6th district firms to similar degree as it did the nation as a whole. To that end, while there is some differences between the 6th district and the nation in the number of COVID-19 cases and deaths attributed to the virus (See Appendix F, figure 27), high-frequency data on the stringency of government response to the virus, measures of retail and workplace mobility, interpersonal engagement, and restaurant bookings in the 6th district broadly mirrored the nation (See Appendix F, figures 28, 29, and 30). The direct regional prevalence of and response to COVID-19 determines the likely disruption to business operations (i.e. mandated shutdowns, temporary closures, employee absenteeism, shift toward a remote working posture, etc.) located and headquartered in the 6th district. However, it is important to note that many of the firms located in the U.S. Southeast have national or international sales presence and exposure to the pandemic through globally interconnected supply chains.

Since its inception, using a method popularized by Manski (2004), the BIE survey has focused on the forward-looking unit costs (nominal marginal costs) of firms, eliciting firms' probabilistic unit cost expectations for the year-ahead on a monthly basis and longer-run (5-10 year-ahead) probabilistic unit-cost expectations on a quarterly frequency. To state it plainly, our view is that firms' unit-cost expectations are their inflation expectations, and aggregating up firms' unit-cost

\footnotetext{
${ }^{5}$ Additional assurances of response quality and external validity such as survey response rates, tenure effects, the impact of question wording, responses to cognitive interviews, and the relationship of BIE responses to other national surveys can be found in Meyer, Parker and Sheng (2020).
} 
expectations yields a measure of inflation expectations that is consistent with firm behavior. As shown in Meyer, Parker and Sheng (2020), this probabilistic measure of the inflation expectations of firms covaries strongly with the inflation expectations of professional forecasters, yields an inflation perception that mirrors current inflation trends, and is highly correlated with a national measure of probabilistic inflation expectations from the Survey of Business Uncertainty (SBU). ${ }^{6}$

While this paper is about understanding how firms are responding to the COVID-19 shock, we acknowledge that many readers will view that previous paragraph as incongruent with the widely cited survey literature from Coibion, Gorodnichenko, and co-authors $(2018,2020)$ on firms' aggregate inflation expectations and it is necessary to lay out an alternative viewpoint. ${ }^{7}$

Much of the confusion around survey measures of inflation expectations is tied directly to the survey respondents' understanding of the concept of "inflation" and its usefulness in their decision making (i.e., whether the respondent understands the concept, has well-formed expectations, and whether the expectations they hold meaningfully impact their behavior). ${ }^{8}$ For the BIE survey, the choice to elicit unit-cost expectation instead of "aggregate" inflation expectations (or price change expectations) was motivated by a variety of theoretical, empirical, and survey design factors.

The microfoundations of the New Keynesian Phillips Curve suggest that firms make pricesetting decisions on the basis of future nominal marginal (unit) costs; see Sbordone (2002). Under general conditions, an expectation of "aggregate" inflation will be an input (embedded) into a firm's unit cost expectations (although, from an individual firm's perspective, this is not a nec-

\footnotetext{
${ }^{6}$ See Altig et al. (2020a) for an overview of the SBU survey and its properties. At the SBU's inception, the survey elicited 1-year ahead unit-cost (inflation) expectations from firms using a question design different from the BIE in the choice to allow respondents to input both the support points and associated probabilities, rather than assigning probabilities to fixed bins. Meyer, Parker and Sheng (2020) evaluate the aggregate responses of the two surveys, finding that the two different methods yielded very similar expectations and uncertainty estimates.

${ }^{7}$ Meyer, Parker and Sheng (2020) build on the survey work by Bryan et al. (2015) to show: question wording matters a great deal to respondents' interpretation of the concept of inflation; in this low inflation environment the U.S. has experienced since 2011 firms may be rationally ignorant of "prices in general" or "prices overall in the economy"; and that eliciting firms unit cost expectations yields a time-series inflation expectations measure that is highly correlated with professional forecasts, uncorrelated with household forecasts, and is far superior in terms of forecasting ability than current household measures of inflation expectations.

${ }^{8}$ See Armantier et al. (2013) and Meyer, Parker and Sheng (2020) for a deeper discussion of question wording ("prices in general/overall in the economy" and expectations for aggregate inflation based on a price index (like CPI or PCE). For evidence of the (lack of) importance firms place in aggregate inflation see Candia et al. (2020) and Meyer, Parker and Sheng (2020).
} 
essary condition). Still, if we hold to this view, each firm's unit cost expectation is the sum of their aggregate inflation expectations and a firm-specific error term, reflecting firm-specific cost structure. ${ }^{9}$ Under reasonable assumptions, e.g. with many firms, the averaged unit cost expectation across firms is a proxy for aggregate inflation expectations. The evidence provided in this paper shows that the aggregated unit-cost expectations of firms are strongly related to the inflation expectations of professional forecasters (see Appendix Figure 16). Moreover, we show that the aggregated unit-cost perceptions of firms covary strongly with actual inflation (see Appendix Figure 15). ${ }^{10}$

Another consideration when choosing to elicit probabilistic unit cost expectations instead of a notion of "aggregate" inflation expectations for firms is that both in cognitive interviews and survey responses (see Appendix figures 23, 24 and 25) firms indicated that unit-costs were more directly relevant to their price-setting decisions than "aggregate" inflation. ${ }^{11}$

One further consideration that is particularly relevant at the moment, is that many surveys of aggregate inflation expectations ask respondents about "prices in general" or "prices overall in the economy". Given the vagueness of the wording, these survey questions are likely to elicit expectations about particular, salient price changes (such as prices of grocery store items or of gasoline). Armantier et al. (2013) and Armantier et al. (2016) provide evidence that changes in wording around the concept of inflation have a material impact on the responses. Moreover, Bryan et al. (2015) and Meyer, Parker and Sheng (2020) highlight that when firms are presented with language that clues them in to the idea that "aggregate" inflation or "prices in general" means changes in the Consumer Price Index, the typical biases tend to dissipate. This is also true of a new survey of firms' inflation expectations from Olivier Coibion and Yuriy Gorodnichenko. ${ }^{12}$ As we

\footnotetext{
${ }^{9}$ Afrouzi (2020) provides evidence that firms in highly competitive environments tend to hold more well-formed "aggregate" inflation expectations.

${ }^{10}$ Meyer, Parker and Sheng (2020) also provide evidence in the cross-section that, individual firm's unit cost expectations are correlated with their expectations for aggregate inflation based on a particular price index (the core CPI) and uncorrelated with their expectations for "prices overall in the economy" or "prices in general."

${ }^{11}$ Further evidence comes from Coibion et al. (2018). They find managers devote few resources to collecting information about aggregate inflation measures and, instead, find information regarding aggregate inflation statistics useful for their shopping experiences.

${ }^{12}$ See https:/ /www.firm-expectations.org. The inclusion of the parenthetical "(for the Consumer Price Index)" in the following question: "What do you think will be the inflation rate (for the Consumer Price Index) over the next 12 months?" essentially clues firms in to the specific inflation concept the researchers wish to investigate. Incidentally, this is nearly identical to a special question posed to the BIE panel back in July 2015 (see https://www.frbatlanta.
} 
discuss in Section 4, we view this pandemic as furthering the distinction between business and household inflation expectations.

In addition to its core focus on inflation expectations, the BIE survey elicits firms' qualitative judgments and quantitative estimates regarding firms' sales levels, margins, and other factors thought to drive businesses' pricing decisions. The questionnaire also contains space for researchers to ask special questions that are policy-relevant, topical, or related to broader academic research. In this paper, we make use of firms' quantitative assessments of their sales "gap" - current sales levels relative to normal - as well as a series of special questions designed to uncover firms' assessments of disruption incurred due to the novel coronavirus, their expectations for their own price changes, and what they anticipate for the path of the virus. A detailed discussion of the data, the specific form of the questions we pose to respondents, and survey descriptions can be found in the appendix. ${ }^{13}$

\section{How do firms view the COVID-19 shock?}

While early news reports of empty grocery shelves have made it clear that the pandemic is crimping some supply chains, at the same time, widespread efforts to control the spread of the virus caused schools, restaurants, and hotels to temporarily close, leading many farmers and food producers to destroy unused food products amid the free-fall in demand. ${ }^{14}$

Cochrane (2020), Kharas and Triggs (2020), and others all point out that the COVID pandemic is unlike a standard recessionary (aggregate demand) shock or a typical inflationary supply shock (oil prices shock). This "health shock" has characteristics of both. Guerrieri et al. (2020) present a model that suggests severe negative supply shocks (like the COVID-19 shock) can lead to a shortfall in aggregate demand that outweighs the effects of the initial supply shock. On the other hand, Abo-Zaid and Sheng (2020) present a dynamic general equilibrium model with a health shock, finding that, while health shocks have significant supply-side effects on economic activity,

org/research/inflationproject/bie/special-questions?pub_year=2015). Importantly, in aggregate, this measure of firms' inflation expectations falls precipitously following the onset of the pandemic, mimicking the behavior of BIE inflation expectations and running counter to the sharp increase in households' "prices in general" expectations.

${ }^{13}$ Further information can be found here: https://www.frbatlanta.org/research/inflationproject/bie

${ }^{14}$ https: / / www.nytimes.com/2020/04/11/business/coronavirus-destroying-food.html 
the demand-side effects are considerably bigger, particularly for shorter horizons and more rigid prices. In relation to both papers, the question is whether firms see the COVID shock, on net, as more of a supply shock or a demand shock. If firms view the pandemic largely as a supply shock, standard theory would expect their unit (marginal) costs to increase amid higher input prices and wages. Firms would also be likely to attempt to pass on these unit cost increases by increasing prices and, ultimately, lead firms to anticipate higher inflation in the future. Firms experiencing a demand shock would behave conversely (experience lower costs, lower wages and prices, and anticipate lower future inflation). ${ }^{15}$

The overwhelmingly negative nature of the shock to firms' sales levels is evident in Figure 1. Recovering from the 2007-2009 financial crisis and recession, firms' quantitative sales gap measure had slowly been moving toward zero (or "normal" sales levels) alongside solid gains in output growth and previously strong job gains. However, that all changed in April 2020. Firms surveyed from April 6 to 10, showed an extraordinarily large decline in sales levels relative to normal from 2.5 percent below normal in the first quarter to 32 percent below normal in April (see the charts). The decline in sales had an impact on firms of all sizes, but smaller firms reported a much larger hit to sales than did firms with more than 100 employees as evidenced in Figure 2. Firms' assessment of sales gaps rebounded somewhat in July, but still remains solidly negative. These results are very similar to the pattern we see in high frequency and macroeconomic data we have in hand thus far into the pandemic. ${ }^{16}$ These patterns are also consistent with other business survey findings that elicit the anticipated impact the coronavirus will have in 2020 (see Altig et al. (2020b) and Bloom, Fletcher and Yeh (2020)). Of course, a sharp widening in the sales gap could be due to either a supply shock or a demand shock.

To disentangle whether firms see COVID-19 as mainly a supply or demand shock, we asked a series of special questions starting in April 2020 as a supplement our core survey question-

\footnotetext{
${ }^{15}$ While there are some clear examples of costs incurred by firms due to the pandemic (i.e. personal protective equipment and plexiglass barriers), it's not clear firms impacted by these cost increases view them as higher marginal or fixed costs. Conversely, there were offsetting cost decreases for many firms (lower energy prices, movements to a work from home posture, and dramatically lower travel costs as external meetings moved online). And, as we show later, many firms experienced lower labor costs.

${ }^{16}$ See Chetty et al. (2020) or visit tracktherecovery.org; Homebase data at https://joinhomebase.com/blog/ an-update-on-small-business-as-covid-19-cases-rise/; Cajner et al. (2020); and Barrero, Bloom and Davis (2020).
} 
Figure 1: Firms' percentage below "normal" sales levels

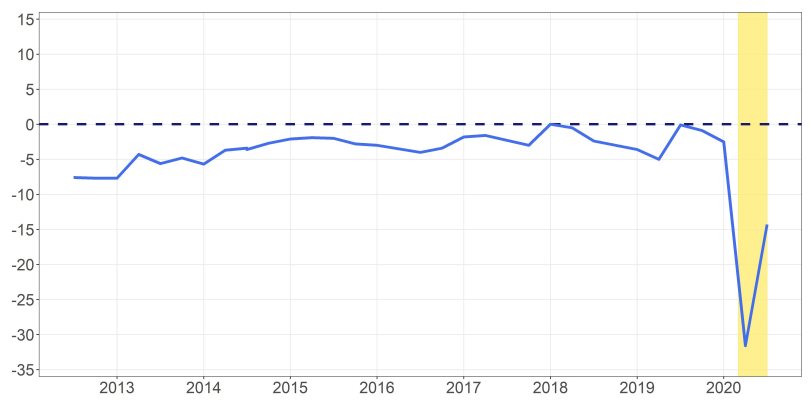

Source: Federal Reserve Bank of Atlanta's Business Inflation Expectations Survey.
Figure 2: Firms' mean quantitative sales gap by firm size

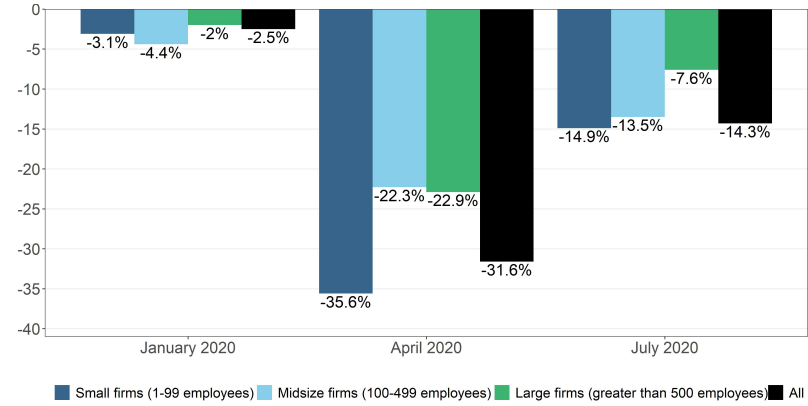

Source: Federal Reserve Bank of Atlanta's Business Inflation Expectations Survey.

naire. Our line of questioning began with attempting to elicit direct responses on the nature of the COVID-related disruption to operations, sales activity, and supply chains. We then related their responses to these questions to changes in expected prices, actual and anticipated changes in wages, and changes to firms' inflation perceptions and expectations.

In April, we asked firms to assess the level of disruption the pandemic has to their business operations, supply chains, sales activity, on a scale of "no disruption" to "severe disruption."17 As shown in Figure 3, more than half the firms surveyed indicated severe disruption to their sales activity and another 18 percent indicated "significant" disruption to sales activity. This compares to just over 10 percent of firms that indicated severe disruption to supply chains. The median respondent indicated moderate disruption to supply chains stemming from the pandemic.

Table 1 relates a firm's response to their level of disruption across business operations, sales activity, and supply chains. The mean sales gap across these categories aligns most closely with disruption to sales activity. Indeed, even firms that indicated no supply disruption had a sharply negative sales gap. Among those firms experiencing severe disruption, sales levels fell to roughly one half relative to normal sales conditions. Similar to Barrero, Bloom and Davis (2020), these results suggest that the disruption associated with the outbreak has not hit all firms equally. There is evidence of dispersion (reallocation) across firms, as a small share of firms that indicated they are

\footnotetext{
${ }^{17}$ In April 2020, we asked about disruption to sales activity and business operations. In May 2020, we asked about disruption to sales activity, supply chains, and staffing levels.
} 
experiencing low levels of disruption are seeing stronger-than-usual sales levels. ${ }^{18}$ Our findings also related favorably to a national survey of CFOs, which in June 2020, elicited firms' most pressing concerns over the previous 3 months in an open text format, finding 6 times more frequent mentions of concerns over flagging demand than over supply chain concerns. ${ }^{19}$ The pandemic

Figure 3: Level of disruption by activity type

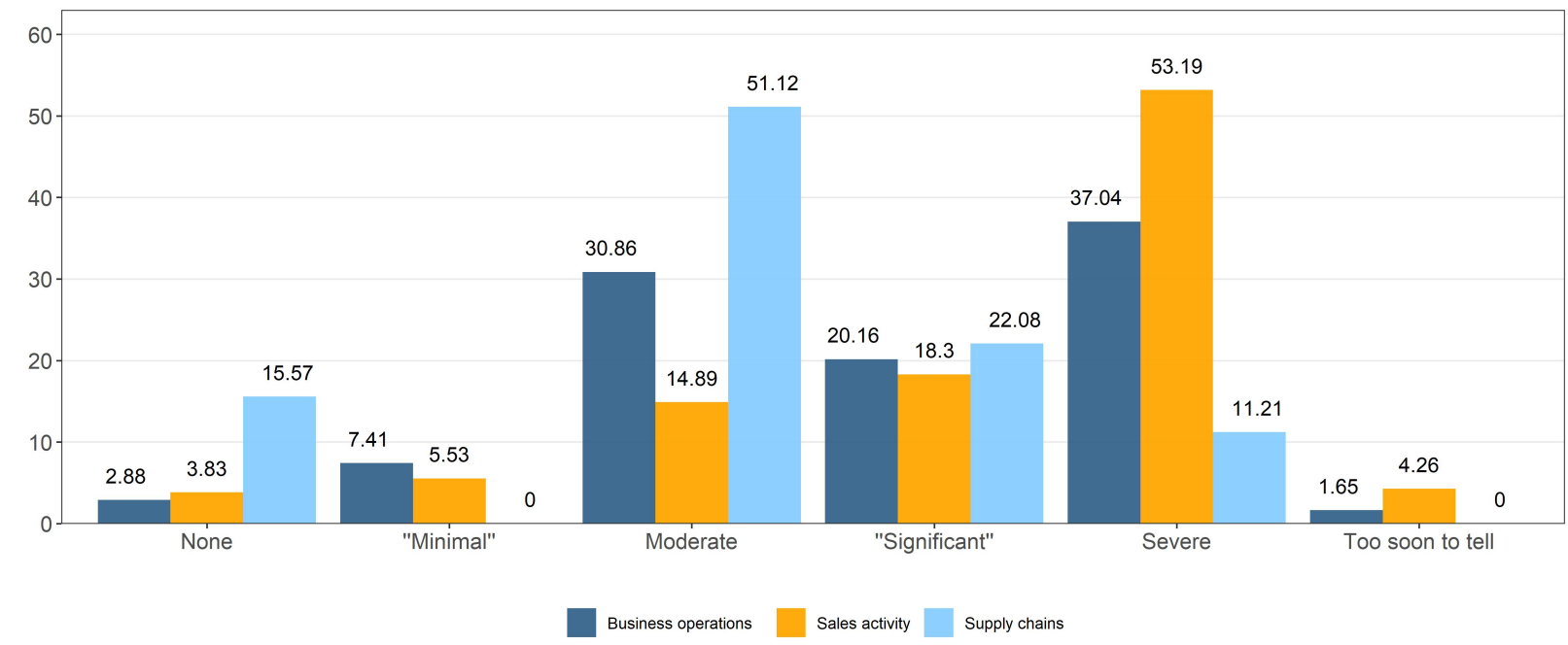

Source: Federal Reserve Bank of Atlanta's Business Inflation Expectations Survey, April and May 2020. Notes: There were 243 observations to the business operations question, 235 to the sales activity question, and 212 to the supply chains question. The supply chains questions did not contain responses corresponding to "Minimal" or "Too soon to tell". The correlation between responses to operations and sales activity: 0.54 , and the correlation between supply chains and sales activity: 0.22 . The specific questions asked are given in Appendix A.

led firms to lower prices. In April 2020, we followed up the disruption questions with a question regarding firms' expectations for their own selling prices over the next 6 months. The intention was to evaluate firms' anticipated price changes by their disruption to sales activity. As Table 2(A) indicates, the majority of firms anticipated holding prices constant over the next 6 months, though nearly twice as many firms anticipated decreasing their selling price than increasing it. For those firms expecting to change their price, the magnitudes are sizeable. The median expectation among

\footnotetext{
${ }^{18}$ Firms that indicated experiencing stronger than normal sales were disproportionately in industries that correspond to the strong shifts in demand that we have seen in Census and high-frequency data (grocers, construction firms, transportation \& warehousing, non-durable goods manufacturers, etc.).

${ }^{19}$ For details: https://www.richmondfed.org/research/national_economy/cfo_survey/research_and_commentary. When the topic of a survey question is wide-ranging, the open-text approach (evaluated using text analysis) tends to be less biasing than having firms choose from a set of response options.
} 
Table 1: Mean quantitative sales gap by level of disruption

\begin{tabular}{cccc}
\hline & Operations & Sales & Supply \\
\hline \hline None & $3 \%$ & $7 \%$ & $-16 \%$ \\
"Minimal" & $-10 \%$ & $4 \%$ & -- \\
Moderate & $-20 \%$ & $-7 \%$ & $-18 \%$ \\
"Significant" & $-19 \%$ & $-15 \%$ & $-43 \%$ \\
Severe & $-51 \%$ & $-52 \%$ & $-55 \%$ \\
\hline
\end{tabular}

Source: Federal Reserve Bank of Atlanta's Business Inflation Expectations Survey, March and April, 2020. Notes: Responses from the financial industry are excluded. There are 206 observations from "operations", 193 from "sales activity", and 166 for "supply". The correlation between quantitative sales gap and sales distribution, disruption to operations, and supply chain disruption is $-0.64,-0.48$, and -0.35 , respectively. The missing value in the Supply column is due to that month's survey having one fewer response option than the operations and sales questions. The specific questions asked are located in Appendix A.

those anticipating to decrease prices over the next 6 months is -13.5 percent. For those anticipating to increase, the median expectation is a 5 percent increase. While, as with sales gaps, there is quite a bit of dispersion in expectations, the thrust of price pressures has a definite downside tilt. Firms, on average, anticipate lowering prices by 2.2 percent over the 6-month period from April to October; see Table 2(B).

Table 2(C) also offers further evidence that firms see the pandemic as a demand shock. The right-hand table shows the mean expected price change by level of sales disruption. Firms indicating no negative disruption to sales activity anticipate increasing selling prices by 4.6 percent on average (nearly every firm expecting to increase prices indicated "no" negative sales disruption in April), while those experiencing severe disruption to sales activity anticipate lowering prices by 3.2 percent, on average.

Panels (A) and (B) in Table 3 corroborate the notion that firms see COVID-19 largely as a demand shock. These tables compare mean expected price changes by variety degrees of sales gap and the severity of supply chain disruption. Interestingly, and counter to what standard theory would suggest about supply shocks, firms that indicated they were experiencing supply chain disruption anticipated lowering prices over the next 6 months, rather than increasing them. For firms experiencing severe supply chain disruption, the mean expected price change was a striking -15.5 percent. And, here a further examination of the microdata indicates that all of the firms ex- 
Table 2: Firms' response to expected price change questions

\begin{tabular}{lr}
\hline Panel A: Share of firms expecting a price change \\
\hline Change in price & Share of firms \\
\hline Increase & $15.0 \%$ \\
Decrease & $26.0 \%$ \\
Remain the same & $59.0 \%$ \\
\hline Panel B: Expected price change over the next six months \\
\hline Statistic & Expected price change \\
Mean & $-2.2 \%$ \\
Median & $0.0 \%$ \\
P10 & $-20.0 \%$ \\
P90 & $5.0 \%$ \\
\hline Panel C: Expected price change by level of disruption to & \\
sales activity & Expected price change \\
\hline Level of sales disruption & $4.6 \%$ \\
\hline None & $-2.5 \%$ \\
"Minimal" & $-0.8 \%$ \\
Moderate & $-1.3 \%$ \\
"Significant" & $-3.2 \%$ \\
\hline Severe &
\end{tabular}

Source: Federal Reserve Bank of Atlanta's Business Inflation Expectations Survey April 2020.

Note: There were 239 observations for the responses in Panels (A)-(C). The specific questions asked are located in Appendix A.

periencing severe supply chain disruption also experienced significant or severe sales disruption as well. The fact that the firms that were doubly impacted by supply chain and sales disruption indicated lowering prices, on average, suggests that COVID-19 has been much more of a demand than a supply shock.

Simply documenting that firms expect to lower prices, on average, over the next six months is insufficient evidence, on its own, to conclude that firms view COVID-19 as a demand shock. For one, a six month window is short enough to be affected by nominal price-stickiness (see Bils and Klenow (2004)), assuming price-setting behavior is time-dependent (see Klenow and Kryvtsov (2008)). Fairness considerations may also have stayed the hands of firms that would have otherwise increased prices (see Kahneman, Knetsch and Thaler (1986)). And, as Gagnon and LopezSalido (2020) point out, this may be particularly true of firms' price-setting strategies surrounding 
Table 3: Firms' expected price change by quantitative sales gap and level of supply chain disruption

\begin{tabular}{lr}
\hline $\begin{array}{l}\text { Panel A: Expected price change by mean } \\
\text { sales gap }\end{array}$ \\
\hline Sales gap & Expected price change \\
$20 \%$ & $-0.5 \%$ \\
{$[-25 \%, 0 \%)$} & $-2.5 \%$ \\
$<25 \%$ & $-4.7 \%$ \\
\hline Panel B: Expected price change by level of disruption to \\
supply chains & \\
\hline Level of supply chain disruption & Expected price change \\
\cline { 2 - 2 } None & $-2.3 \%$ \\
"Some" & $-2.0 \%$ \\
"Significant" & $-15.5 \%$ \\
Severe & \\
\hline
\end{tabular}

Source: Federal Reserve Bank of Atlanta's Business Inflation Expectations Survey April 2020.

Note: There were 239 observations for the responses in Panels (A) and 189 for the responses in panel (B). Of the firms experiencing severe supply chain disruption in Panel (B), all of them noted significant or severe sales disruption as well. The specific questions asked are given in Appendix A.

an unexpected (and large) demand shock.

Still, our evidence suggests that firms' expected near-term pricing decisions are related to whether their sales activity has been negatively disrupted by COVID-19. This is just one piece in a collection of evidence (including firms' direct responses to questions regarding supply and demand shocks, their current and forward-looking wage decisions, and their inflation expectations) that indicate, on net, firms view the pandemic as a demand shock.

In addition to firms' expected price changes, we also offer evidence from firms' wage-setting behavior that corroborates the view that firms see COVID-19, on net, as a demand shock. In August 2020, we asked firms in the BIE to, first, characterize their workforce between "high-skilled" and "low-skilled" labor and followed up with questions eliciting what share of their (high-andlow skilled) workforce as seen increases, decreases, or no change in their wages since the onset of the COVID-19 pandemic. We followed with a similar question on anticipated wage changes from the current period until the end of 2020.20

\footnotetext{
${ }^{20}$ See Appendix A for the specific wording to these and all survey questions used in this paper.
} 
Figure 4 shows that firms cut nominal wages for 10 percent of continuing employees, a result that is nearly identical to what Cajner et al. (2020) find using administrative payrolls data. The apparent lessening of downward nominal rigidity during the COVID-19 pandemic is quite unusual. As Cajner et al. note in their paper, the prevalence of these wage cuts are roughly twice what continuing employees experienced during the entirety of the Great Recession. ${ }^{21}$ Interestingly and perhaps somewhat worrisome, our results suggest that firms anticipate further negative wage adjustments by the end of the year.

Figure 4: Firms' Experienced and Expected Wage Changes

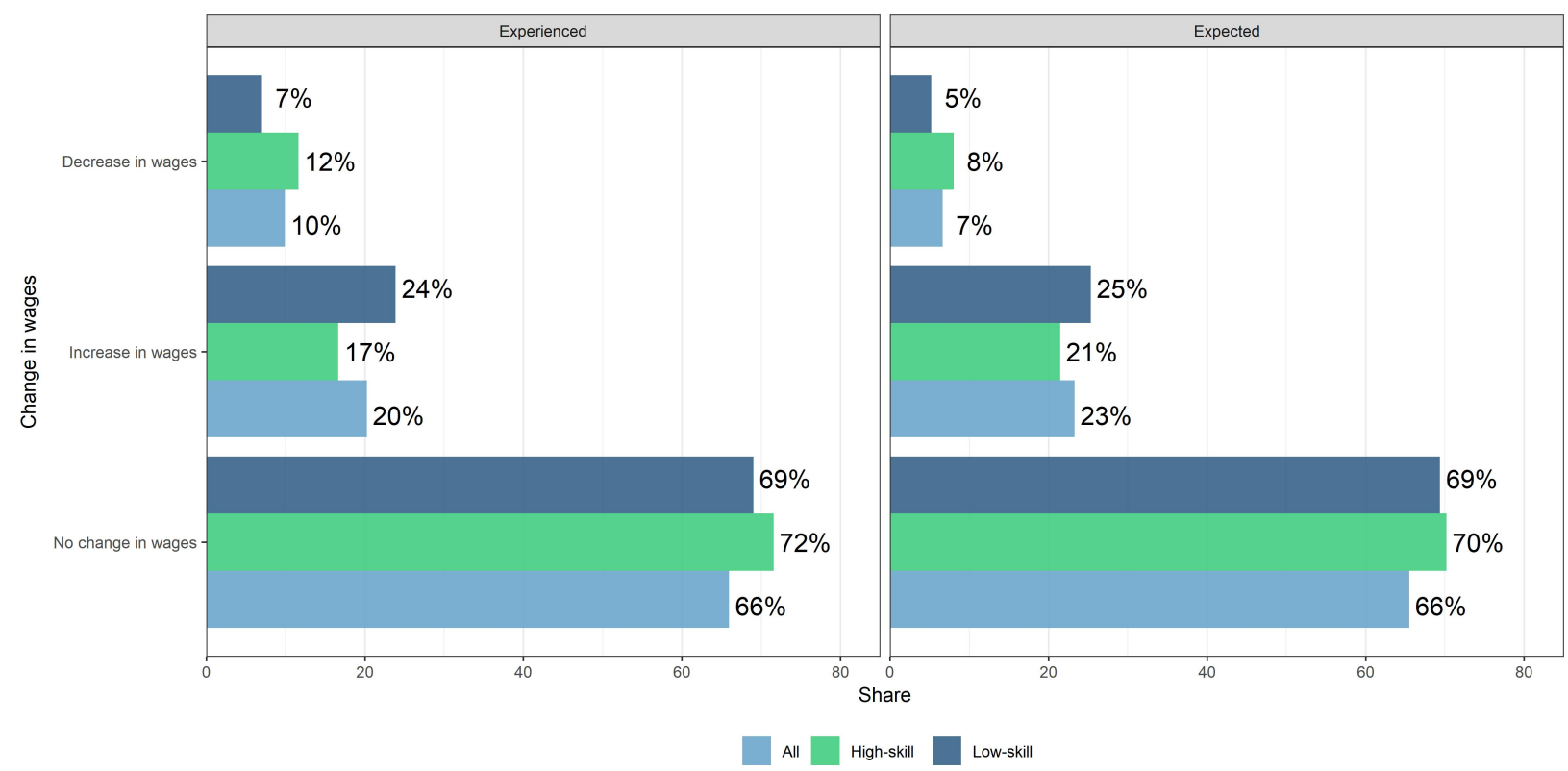

Source: Federal Reserve Bank of Atlanta's Business Inflation Expectations Survey, August 2020. Notes: Respondents were only asked about their wage changes for a skill level if they indicated the presence of a low-skill or high-skill workforce. There were 160 responses for the low-skill experienced and expected wage change, 175 for the high-skill experienced wage change, and 176 for the high-skill expected wage change. The specific questions asked are given in Appendix A.

Figure 5 sheds further light on the nature of the COVID-19 shock. Firms hit the hardest by the shock are those that are disproportionately engaging in wage cuts. This holds both for the

\footnotetext{
${ }^{21}$ This phenomenon is also unusual in the history of the BIE. While not directly comparable to our current results, in September 2018 we elicited firms' year-ahead probabilistic wage growth expectations. Only one respondent at the time indicated the potential for negative wage growth in a "lowest-case" expectation. See the BIE's special question archive for 2018 (https:/ / www.frbatlanta.org/research/inflationproject/bie/special-questions.aspx?pub_year=2018) for more details.
} 
severity of the sales disruption and for the severity of the shortfall in firm's quantitative sales gap. These responses on the part of business decision makers to cut wages given dramatic declines in sales activity and amid severe disruption due to the pandemic further bolster the claim that demand shocks are overpowering the supply shocks. If supply shocks were dominating, standard theory would suggest upward pressure on wages. These results stand in contrast to the findings by Brinca et al. (2020) that use a structural Bayesian VAR to decompose changes in hours worked by sector into supply and demand shock contributions and conclude that the supply shocks dominate. Our results indicate that firms view the enormous impact that the pandemic is having on

Figure 5: Firms' experienced and expected wage changes by quantitative sales gap and level of sales disruption

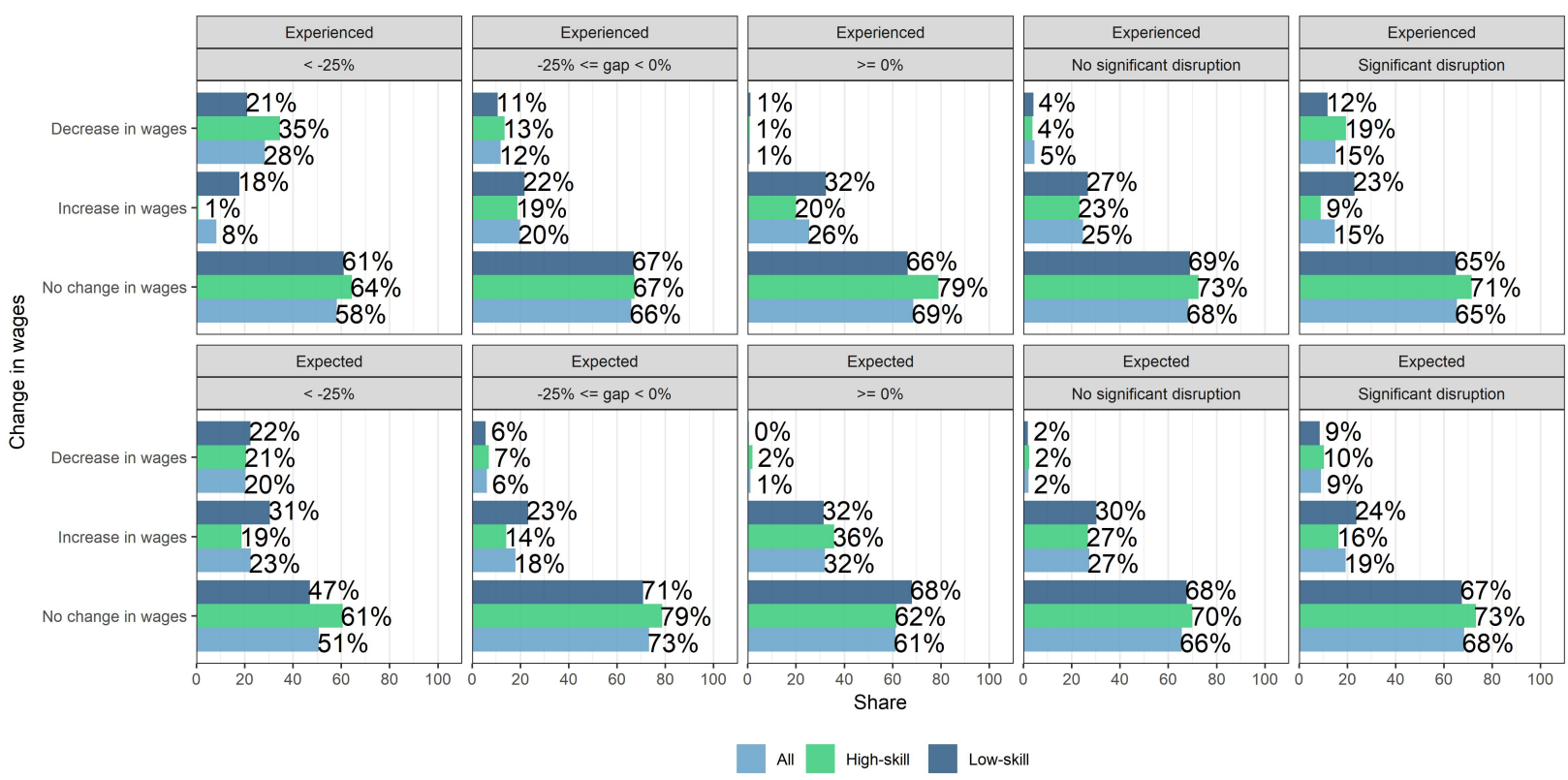

Source: Federal Reserve Bank of Atlanta's Business Inflation Expectations Survey July and August 2020. Notes: The low-skill expected and experienced values are based on were 149 responses, 164 and 165 responses to the high skill questions, and 332 responses for the all sales disruption category. Additionally, the sales gap category had 152 responses for the low-skill expected and experienced values, 167 and 168 responses to the high skill questions, and 338 responses for the all category. The specific questions are given in Appendix A.

economic activity as, on net, a demand shock. Firms anticipate, on average, lowering prices in the near future and much of that downward price pressure is stemming from firms disproportionately impacted by the virus (even among those that noted significant or severe supply chain 
disruption). These findings are supported by the material (and unusually high) share of negative nominal wage adjustments that we have seen so far during this crisis and those that firms' anticipate over the remainder of the year. Moreover, other business surveys, such as in Bartik et al. (2020) tell a consistent story. In fact, they note, "Respondents that had temporarily closed [early in the pandemic] largely pointed to reductions in demand and employee health concerns as the reasons for closure, with disruptions in the supply chain being less of a factor." 22 We view these results as corroborating evidence. And, while the BRS shows the breadth of demand vs supply shocks, our work is able to further disentangle how firms perceived these shocks through their behavior and expectations.

\section{COVID-19's Impact on Inflation Expectations}

Alongside the freefall in demand, COVID-19 has also significant impact on inflation expectations. Specifically, the pandemic has lowered businesses' and professional forecasters' inflation expectations over the year-ahead, while, simultaneously causing household inflation expectations to increase markedly. In this section, we provide evidence that firms and households view COVID-19 in fundamentally different ways, with firms and forecasters responding to the shock by ratcheting down their expectations in sharp contrast with the expectations held by households.

Consistent with firms' collective judgment that COVID-19 is more of a demand than supply shock, they have ratcheted down their inflation expectations markedly. Businesses' probabilistic 1-year ahead inflation expectations fell to a series low of 1.4 percent in April 2020. Figure 6 shows the distribution of respondents' expected values. A clear downshift in expectations is evident starting in April 2020. ${ }^{23}$ Prior to April, the majority of firms' expectations were centered on 2 percent and there was very little mass in the tails. We can also see this downshift in the mean

\footnotetext{
${ }^{22}$ The BLS very recently released the results of its 2020 Business Response Survey (BRS) which finds 56 percent establishments (approximately 4.7 million) experienced a decrease in demand during the pandemic (through September 2020), while only 36 percent of establishments (or 3.1 million) experienced a shortage of supplies or inputs (for details see: https:/ / www.bls.gov/brs/2020-results.htm).

${ }^{23}$ Many view the beginning of the COVID pandemic as occurring on March 13, 2020 and corresponding with shelterin-place orders happening across the country. The March BIE was in the field from March 2-6, prior to this period. Moreover, a special question posed to the panel in March asked if the recent coronavirus outbreak had an effect on a number of aspects of business activity. The results indicated that, outside of a few firms, the majority of the business community had yet to be impacted.
} 
probabilities assigned to each bin. After the onset of the pandemic, the mean probability assigned to the lowest bin (corresponding to negative cost growth) nearly doubled - from 6 percent to 11 percent.

Figure 6: Distribution of firms' short-run inflation expectations from January to August 2020

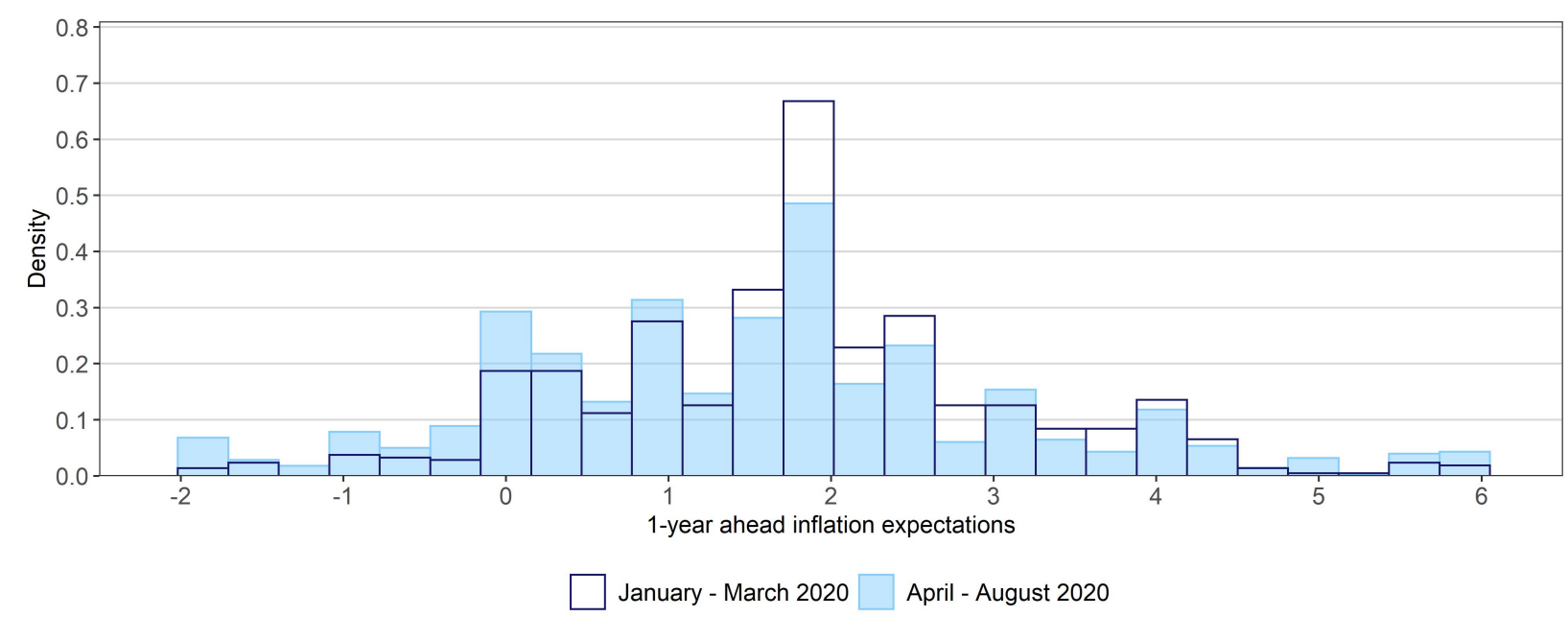

Source: Federal Reserve Bank of Atlanta's Business Inflation Expectations Survey; January to August 2020. Notes: There were 690 and 1,113 responses in the pre-COVID and COVID time periods, respectively. The specific question is given in Appendix A.

Figure 7 compares 1-year ahead inflation expectations across businesses (from the BIE survey), professional forecasters (SPF survey), and households (from the University of Michigan and from the New York Fed's Survey of Consumer Expectations (SCE)). ${ }^{24}$ The yellow shaded area corresponds with the COVID-19 pandemic. The stark contrast in responses between firms and professionals (sharply lowering expectations) and households (sharply increasing expectations) is clear. It is worth noting that all three of these groups held higher inflation expectations in 2018, a period marked by escalating tension over global trade, increased tariffs, and higher costs of production. Figure 8 plots 1-year ahead uncertainty measures from these three groups, and, again, the difference between the reaction from businesses and professionals to that of households is clear. By May 2020, household 1-year ahead inflation uncertainty in the SCE had jumped up to a series high (the series began in mid-2013). On the other hand, inflation uncertainty measures of firms and pro-

\footnotetext{
${ }^{24}$ For background on the SCE, see Armantier et al. (2013).
} 
Figure 7: Inflation expectations of consumers, firms, and professionals
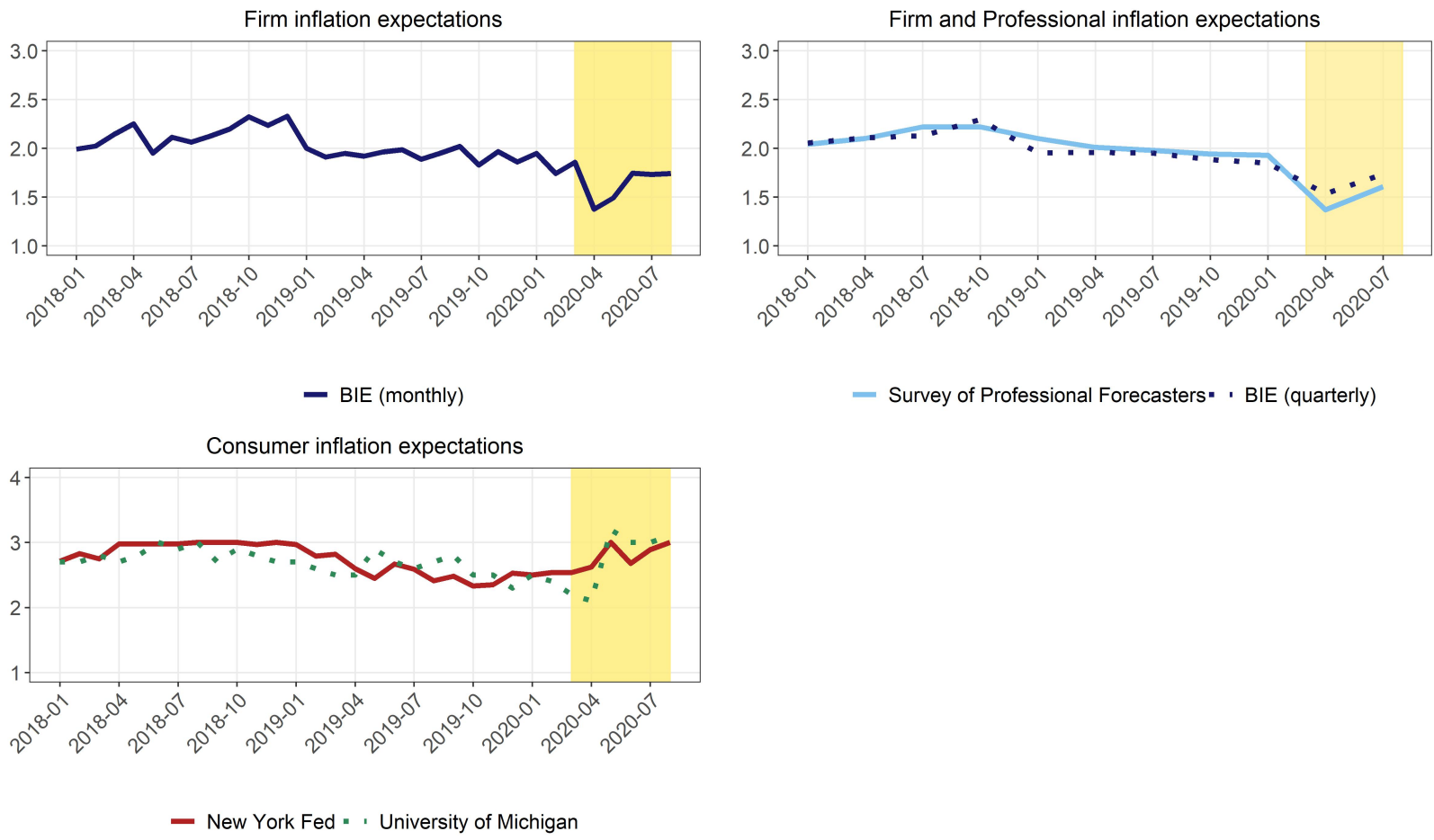

Source: Federal Reserve Bank of Atlanta's Business Inflation Expectations Survey, Federal Reserve Bank of New York's Survey of Consumer Expectations, Federal Reserve Bank of Philadelphia's Survey of Professional Forecasters, and the University of Michigan's Survey of Consumers.

Notes: The yellow shaded regions begin in March 2020 and signal the onset of the COVID-19 pandemic in the U.S.

fessional forecasters ticked up, but remained below their respective levels in 2018-19. Firms, in particular, do not appear to be overly uncertain about the likely direction over the coming year. Despite the severity of the crisis and consistent with lower demand, on net, firms expect inflation to slow.

These results do raise the question as to why well-known measures of household inflation expectations have risen sharply in the wake of the COVID-19 pandemic. Here, we highlight that the recent household survey literature around the pandemic's impact on inflation expectations finds mixed results. A high-frequency consumer survey conducted by the Cleveland Fed, designed to understand how consumers are reacting to COVID-19, indicated early on in the consumers anticipate inflation to increase by roughly 5-7 percentage points over the next year as a result of the 
Figure 8: Inflation uncertainty of consumers, firms, and professionals
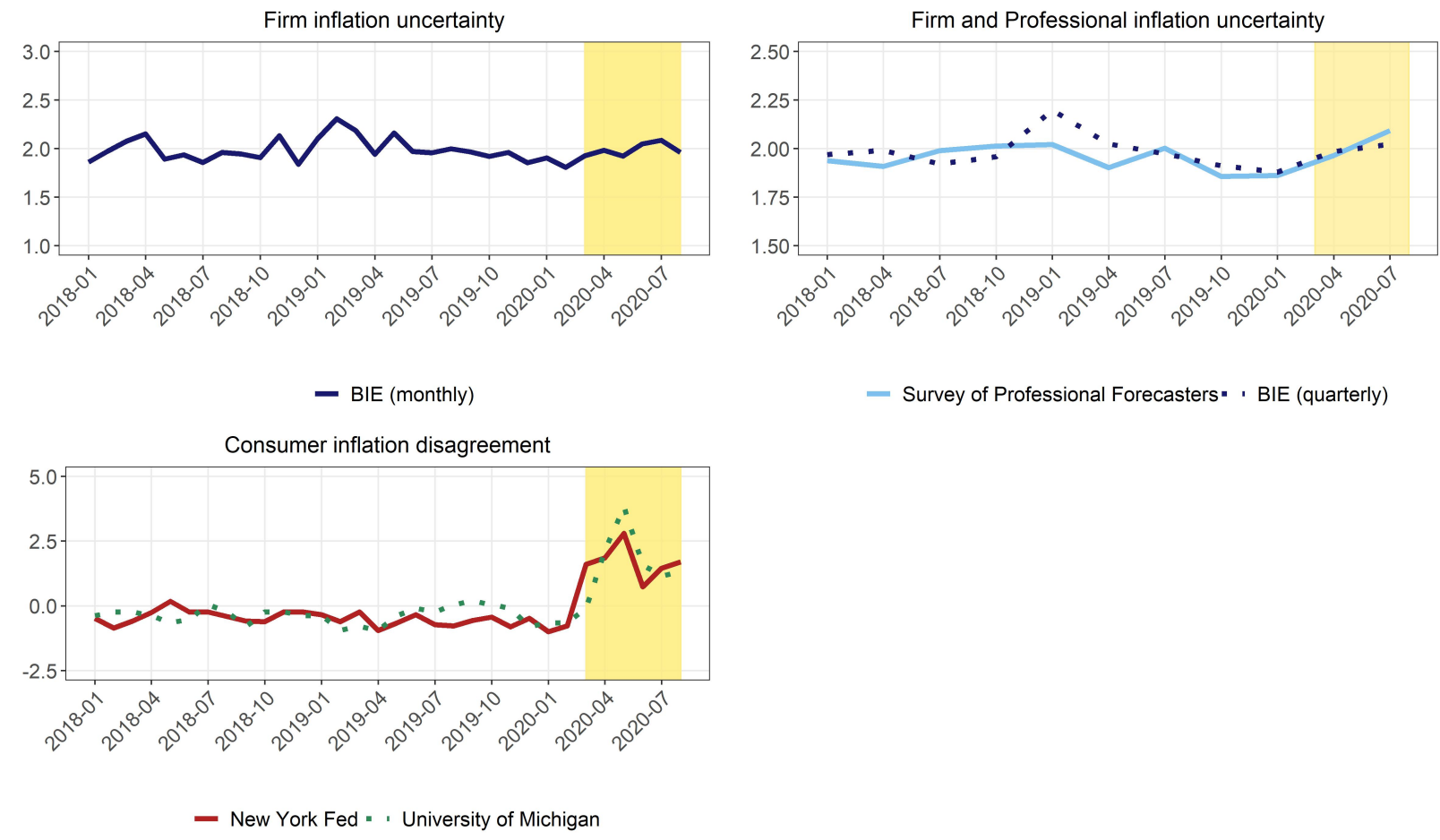

Source: Federal Reserve Bank of Atlanta's Business Inflation Expectations Survey, Federal Reserve Bank of New York's Survey of Consumer Expectations and Federal Reserve Bank of Philadelphia's Survey of Professional Forecasters.

Notes: Uncertainty for the BIE is measured as the mean of the variance of firm inflation expectations, while it is measured as the dispersion between the forecasts for the SPF. Additionally, the SPF series is re-scaled to the level of the quarterly BIE. The yellow shaded regions begin in March 2020 and signal the onset of the COVID-19 pandemic in the U.S.

COVID-19 shock. ${ }^{25}$ Armantier et al. (2020) find the COVID-19 shock had a disparate impact on demographic groups, with higher educated (and, presumably, higher income) individuals actually lowering their inflation expectations. Following a probabilistic approach used by the BIE and in the NY Fed's SCE, Coibion et al. (2020) find households under lockdown actually lowered their inflation expectations moderately. ${ }^{26}$ And, Binder (2020a) finds household inflation expectations vary by their level of concern regarding the effect of coronavirus on the U.S. economy, with those concerned tending to have much higher inflation expectations.

\footnotetext{
${ }^{25}$ https: / / www.clevelandfed.org/en/our-research/indicators-and-data/consumers-and-covid-19.aspx

${ }^{26}$ They note, "asking specifically about inflation, because asking about prices might induce individuals to think about specific items whose prices they recall rather than about overall inflation."
} 
The divergence between the inflation expectations of businesses and households may, in part, be due to how sensitive these two groups are to particular relative price changes in the economy. Consistent with a notion forwarded in Coibion et al. (2020), households may be (over)reacting to spiking grocery store prices. Indeed, the upper tail of the Consumer Price Index price-change distribution from March through August 2020 is dominated by these salient consumer goods (see figure 9). And, consistent with Binder (2020a), it may be the case that those most concerned by the coronavirus are those most vulnerable to spikes in food prices. Among respondents to the University of Michigan's survey, the sharpest increase in inflation expectations has come from those individuals in the lower tercile of the income distribution. Given the substantial amount of disinflation in the overall CPI since the onset of the pandemic-slowing from a year-over-year growth rate of 2.3 percent in February to just 1.3 percent as of August-it certainly appears that households may be overreacting to surging grocery store prices.

Figure 9: Consumer price index component price change distribution

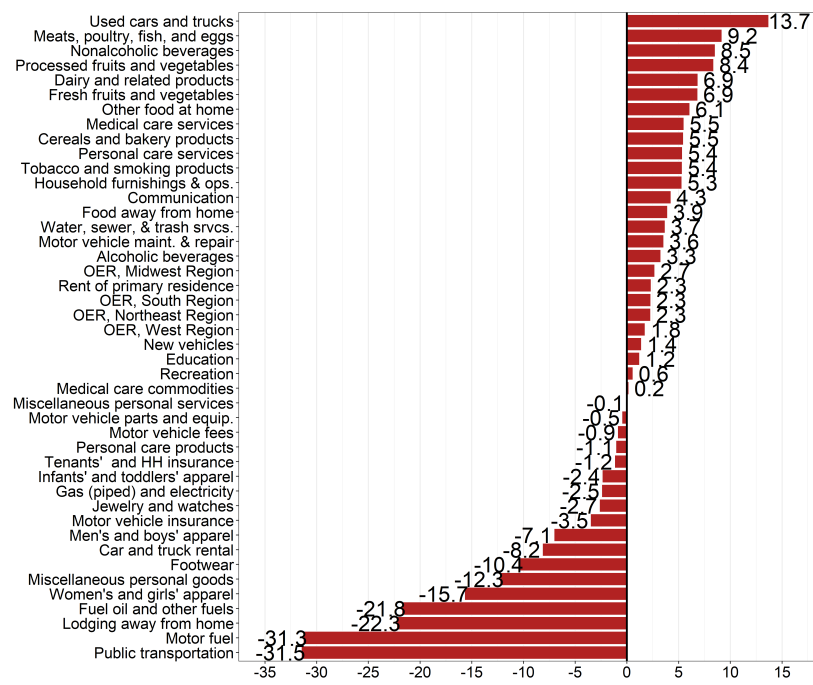

Source: Bureau of Labor Statistics; author's calculations.

Note: We are reporting the annualized percent change over the time period spanning March 2020-August 2020.
Figure 10: Pandemic impact on price indexes: changes in expenditure share / relative important

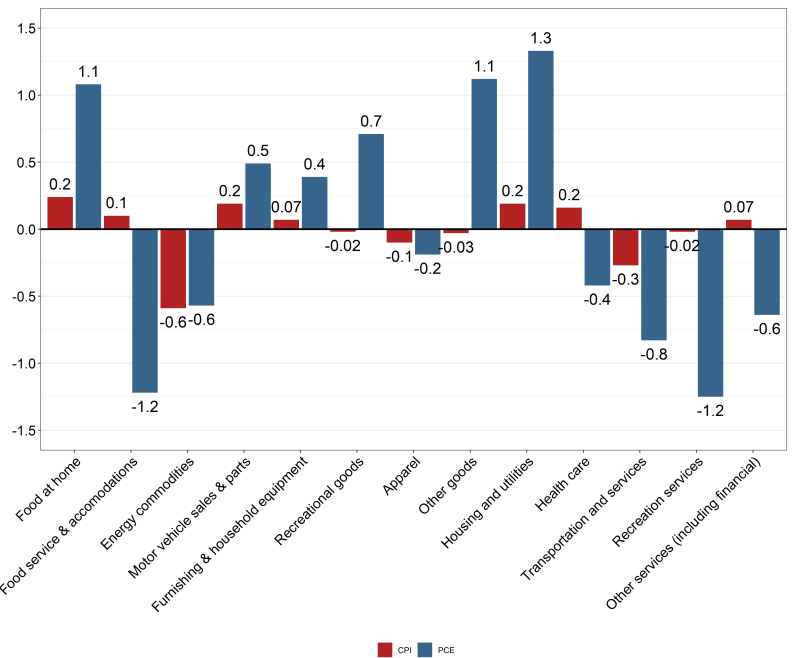

Source: Bureau of Labor Statistics; Bureau of Economic Analysis; author's calculations.

Note: The data reported is in percentage points and is from December 2019 to August 2020.

However, the COVID-19 pandemic has led to a dramatic shift in consumer preferences and 
expenditures-replacing experiential spending at restaurants, tourist locations, and other servicebased spending with durable goods and increase spending at the grocery store. Indeed, many of the very categories that have registered large price increases are those that are experiencing the largest changes in spending (see figure 10). Moreover, these changes in expenditures are not captured using the CPI's "fixed-basket" weighting methodology. Unlike the CPI, the Personal Consumption Expenditures (PCE) Chained-Price Index does account for changes in spending patterns. The market-based variant of the PCE price index (the closest comparison to the CPI) has slowed by 40 basis points on a year-over-year basis, a smaller decline than the overall CPI. While this is not the central focus of the paper, the enormous impact that the pandemic has had on retail prices and consumer spending-patterns has further highlighted the notion that households may be responding to salient relative price changes instead of "aggregate" inflation when asked to give their expectation about "prices in general" or "prices overall in the economy."

Firms, in contrast to households, appear to be responding to changes in their own unit costs rather than salient items in the consumer market basket. Appendix figures 17 and 18 show that firms' perceived changes in unit costs and unit cost expectations vary by industry group, but, once aggregated, mirror changes in overall inflation and align well with the expectations of professional forecasters. One piece of evidence that corroborates the view that firms appear to be responding to changes in their own unit costs comes from an excellent decomposition of the ex food and energy ("core") PCE price index into COVID-sensitive and insensitive sectors by Shapiro (2020). This compensation reveals a sharp decline in COVID-sensitive inflation driven by sizeable declines in both price and quantity, consistent with a demand shock.

While it is not entirely clear what is driving common measures of household inflation expectations higher, ${ }^{27}$ it is apparent that firms, like professionals, have lowered their year-ahead inflation expectations consistent with a demand shock. We turn next to firms' longer-run (5-10 year ahead) inflation expectations.

\footnotetext{
${ }^{27}$ Kamdar (2019) finds that sentiment is a key driver of household macro expectations and many households equate "bad times" with "high inflation." See also Binder (2020b).
} 


\section{Long-run Inflation Expectations Appear Anchored for Now}

The pandemic has led firms, en masse, to lower their near-term inflation expectations in a manner consistent with a demand shock. However, as shown in Figure 11 firms' longer-run inflation expectations are little changed. On average, firms' longer-run expectations ticked down by 0.1 percentage points from March 2020 to June 2020. There is little evidence of a large shift in the crosssectional distribution during these early months of the pandemic. Perhaps more importantly,

Figure 11: Distribution of firms' long-run inflation expectations from January 2020 to June 2020

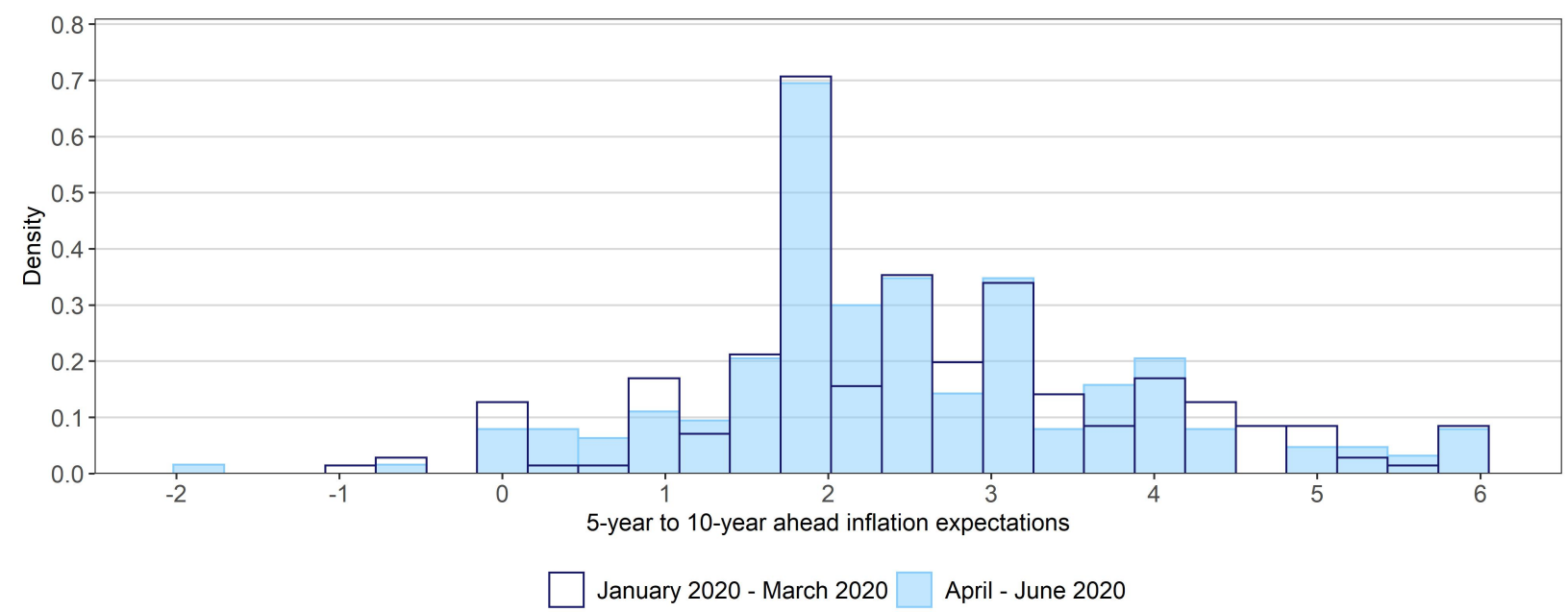

Source: Federal Reserve Bank of Atlanta's Business Inflation Expectations Survey, January 2020 and June 2020.

Notes: There were 228 and 204 responses in the pre-COVID and COVID time periods, respectively. The specific question is given in Appendix A.

firms that lowered their inflation expectations between March 2020 and June 2020 do not appear to have ratcheted their longer-run expectations down in concert. Exploiting the panel structure of the BIE, Figure 12 reveals no meaningful relationship over the pandemic period between a firm's change in their short-run expectations and the change in their longer-run expectations. In the parlance of Fedspeak, businesses' inflation expectations remain well-anchored. 
Figure 12: Changes in long-run and short-run inflation expectations

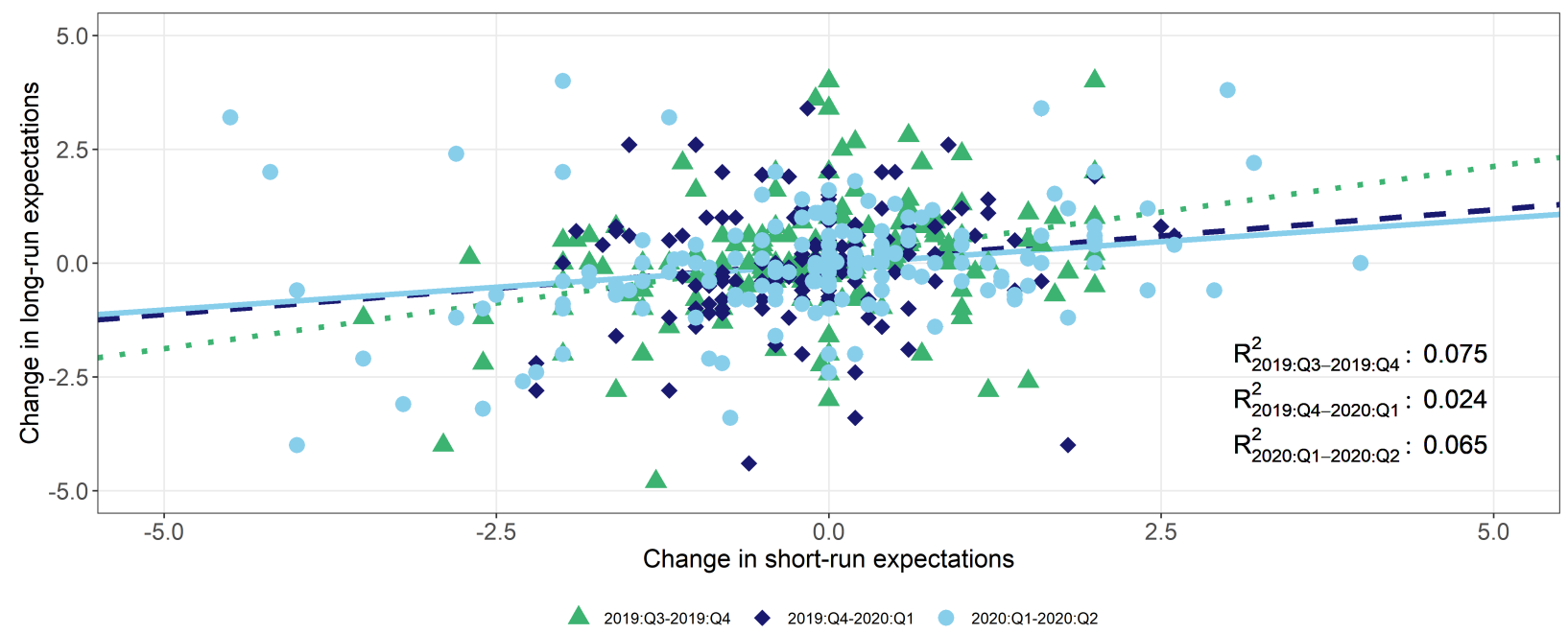

Source: Federal Reserve Bank of Atlanta's Business Inflation Expectations Survey; September 2019, December 2019, March 2020, and June 2020.

Notes: Both the x-axis and y-axis report the difference in percentage points. The solid fitted line belongs to the period December 2019 to March 2020 (pre-COVID) while the dashed fitted line belongs to the period March 2020 to June 2020 (COVID). There were 192 respondents who completed both September 2019 and December 2019, 188 respondents who completed the December 2019 and March 2020 survey, 173 respondents completed the March and June 2020 surveys. The specific questions asked are given in Appendix A. The $x$-axis is truncated at the $[-5,5]$ interval to more clearly show the variation between short and long-run expectations. The fitted lines are computed separately by the equation:

$\Delta \pi_{f, t, t+\ell}^{\mathrm{E}}=\alpha+\beta \Delta \pi_{f, t, t+1}^{\mathrm{E}}+\epsilon_{f t}$. The slope of the fitted line for the period 2019:Q3 to 2019:Q4 is 0.40. The slope of the fitted line for 2019:Q4 to 2020:Q1 is 0.20. The slope of the fitted line for the period 2020:Q1 to 2020:Q2 is 0.23.

\section{Conclusion and Short Discussion}

Since mid-March 2020, the coronavirus pandemic has had a profound impact on the U.S. as efforts to stem the spread of the virus led to shutdowns of large swaths of the economy. Business operations, sales activity, and (to a lesser extent) supply chains have all been disrupted. Our results suggest that firms, on net, have viewed this crisis largely as a demand rather than a supply shock. Firms, responding to this demand shock, have lowered wages for a material share of their workforce, anticipate further wage cuts before the end of 2020, and anticipate lowering selling prices over the near-term.

Also, consistent with a demand shock, firms (like professional forecasters) lowered their 1- 
year ahead inflation expectations. Concurrently, inflation expectations of households have moved sharply higher, consistent with households' keying off salient prices or concerned with how vulnerable their nominal income is to the pandemic and their ability to manage in the face of sharp food price increases.

Our findings contribute to the rapidly emerging literature that examines direct effects of the pandemic on business ability to operate. Ramelli and Wagner (2020) show firms' stock prices were adversely affected when they were more dependent on international trade, global supply chains, and financial markets, with these effects becoming more pronounced by March. Alfaro et al. (2020) and Fahlenbrach et al. (2020) find similar results. Bartik et al. (2020) find similar operating and liquidity concerns for small businesses who have been especially affected by enforced lockdowns yet employ nearly fifty percent of American workers. Dingel and Neiman (2020) also show the effects may be heterogeneous as the proportion of jobs that can still be done under lockdown measures varies by industry.

From a monetary policy standpoint, perhaps the only point of solace here, is that longer-run inflation expectations of firms appear to be relatively well anchored. However, since mid-June, the path of the virus has accelerated and we have seen more and more hotspots emerging across the U.S. At the same time, the high-frequency data of Brave et al. (2019), Chetty et al. (2020), and other sources suggest economic activity has flattened out and begun, in some cases, to show signs of slowing. Here our findings are, perhaps, less comforting to policymakers.

Table 4: Expected number of months until business operations return to normal

\begin{tabular}{lcccccc}
\hline & Mean & Median & P10 & P25 & P75 & P90 \\
\hline \hline April 2020 & 5.1 & 4.0 & 2.0 & 3.0 & 6.0 & 10.0 \\
July 2020 & 9.3 & 9.0 & 3.0 & 6.0 & 12.0 & 18.0 \\
\hline
\end{tabular}

Source: Federal Reserve Bank of Atlanta's Business Inflation Expectations Survey, April and July, 2020. Notes: Notes: There were 220 observations in April 2020 and 198 in July 2020. The specific question is given in Appendix A.

In April 2020 and again in July 2020, we asked firms to predict when the coronavirus would be behind them and they could get back to normal operations. Back in April, firms gave us responses that aligned well with Bartik et al. (2020). At the time, half of the panel expected normal 
Figure 13: Cumulative share of the expected number of months until operations return to normal

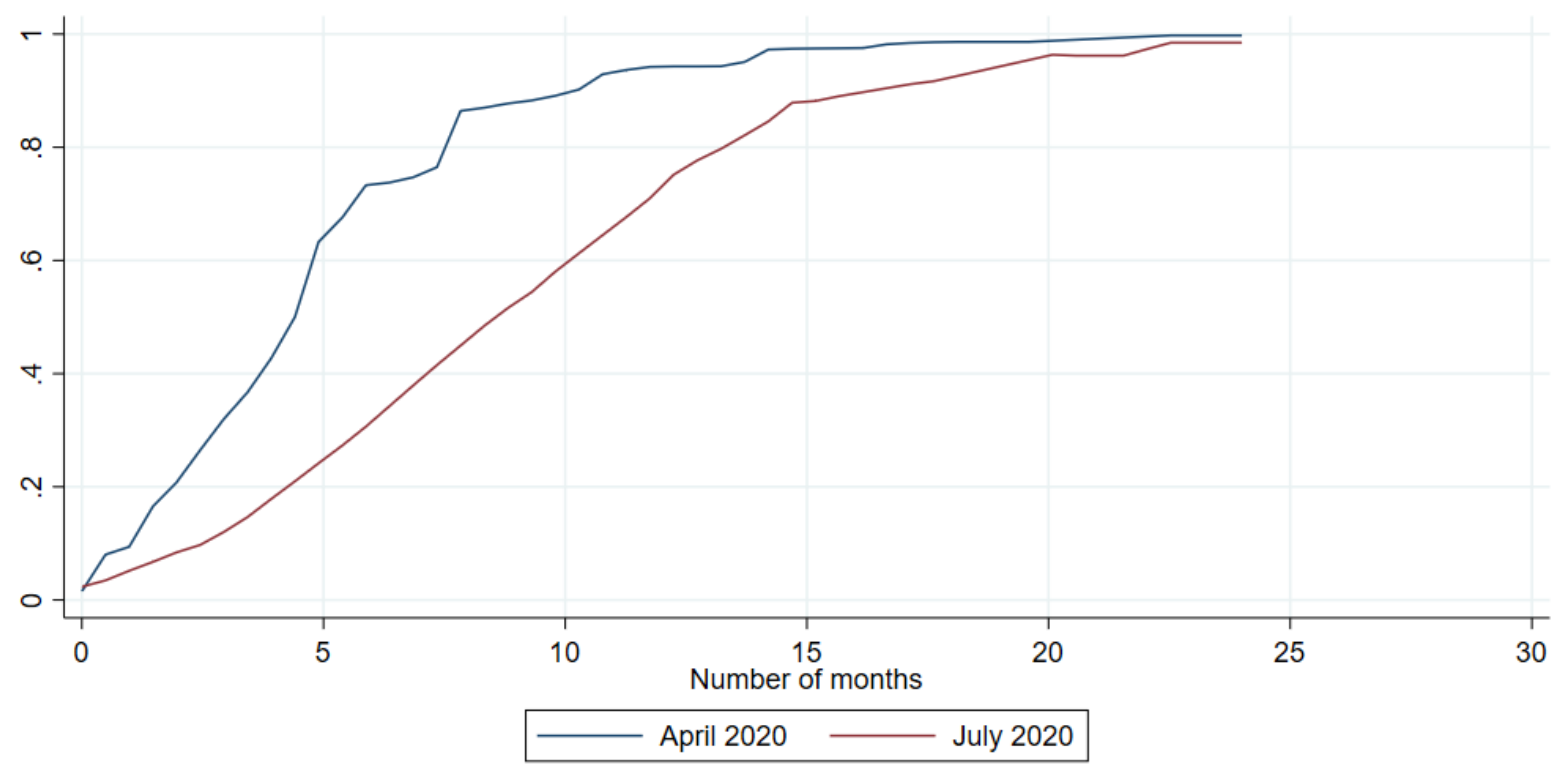

Source: Federal Reserve Bank of Atlanta's Business Inflation Expectations Survey, April and July 2020. Notes: The responses are smoothed using a $1^{\text {st }}$ degree polynomial smoother and are truncated at the $99^{\text {th }}$ percentile. The specific question is given in Appendix A.

operations would resume by August 2020, and the most pessimistic firms (90th percentile) saw the coronavirus lasting until March 2021. However, firms have grown much more pessimistic since then. We repeated this question in July, and as Figure 13 indicates, the typical firm in July expects the pandemic to continue to disrupt normal business operations until April 2021. And, about 10 percent of the firms see the crisis lasting until the beginning of 2022. Moreover, as shown in Figure 14, firms that anticipate a longer duration of disruption from the coronavirus are also those that have indicated cutting a greater fraction of their employees' wages. These findings suggest that firms' expectations for the path of the virus could already be influencing their beliefs about the current and expected state of the labor market and, importantly, about future demand.

Should the COVID-19 linger over the U.S. for another 12 months or longer, bringing with it lower demand, further shutdowns, and negative sales gaps, it could lead to lasting scars (see Portes (2020)). Firms may respond by lowering wages further, lowering inflation expectations further or, perhaps, unanchoring longer-run expectations to the downside. 
Figure 14: Firms' Experienced and expected wage changed by expected duration of the pandemic

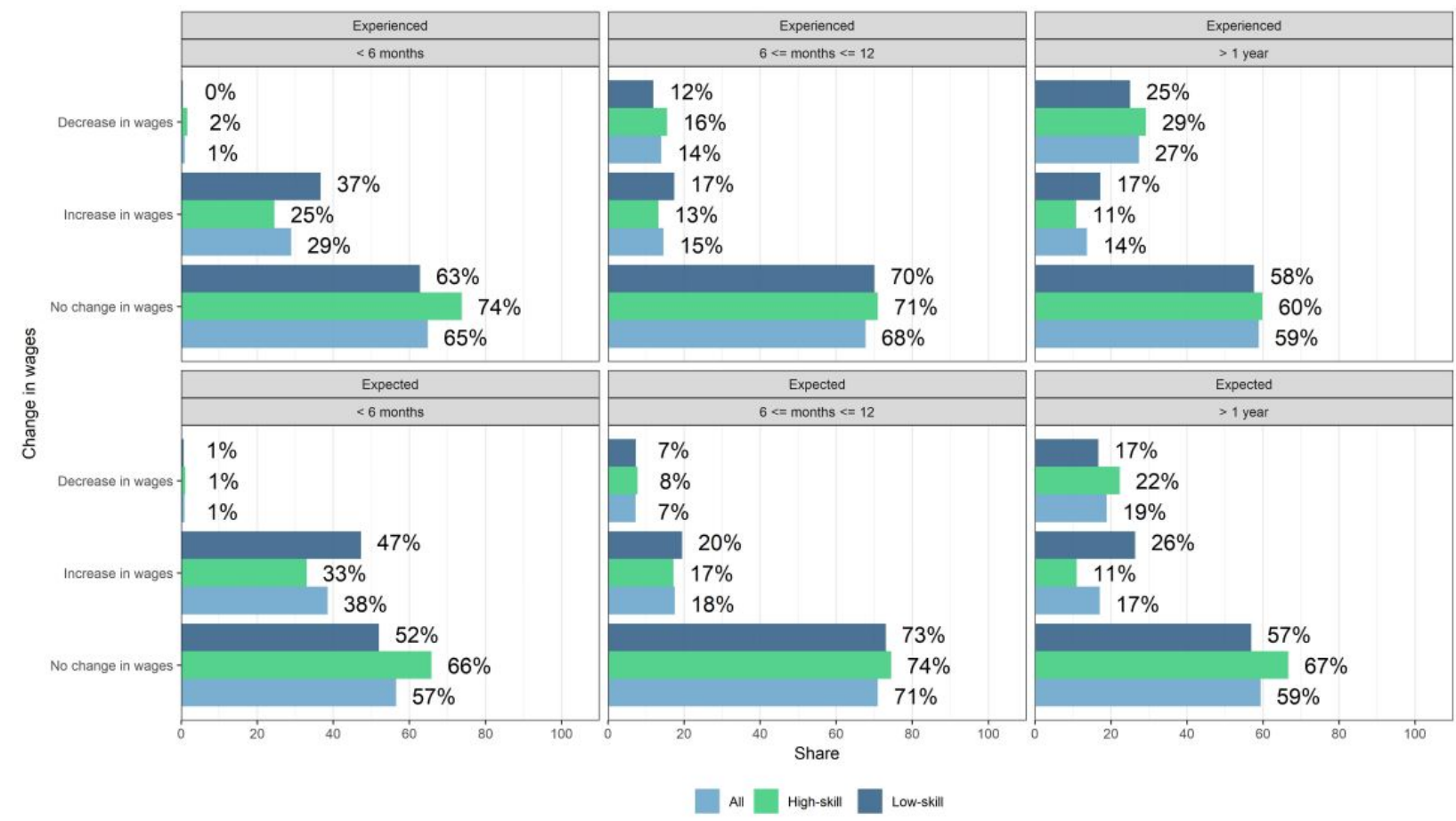

Source: Federal Reserve Bank of Atlanta's Business Inflation Expectations Survey, July and August 2020.

Notes: The low-skill expected and experienced values are based on 135 responses, 148 and 149 responses to the high-skill questions, and 300 for the all category. The specific questions asked are given in Appendix A.

\section{References}

[1] Abo-Zaid, S. and X.S. Sheng (2020). Health Shocks in a General Equilibrium Model. Working paper.

[2] Afrouzi, H. (2020). Strategic Inattention, Inflation Dynamics, and the Non-Neutrality of Money. CESifo working paper No. 8218.

[3] Alfaro, L., A. Chari, A. Greenland, and P. Schott (2020). Aggregate and Firm-Level Stock Returns During Pandemics in Real Time. NBER Working Paper No. 26950

[4] Altig, D., J.M. Barrero, N. Bloom, S.J. Davis, B.H. Meyer, E. Mihaylov, and N. Parker (2020a). Surveying Business Uncertainty. Forthcoming in Journal of Econometrics.

[5] Altig, D., J.M. Barrero, N. Bloom, S.J. Davis, B.H. Meyer, E. Mihaylov, and N. Parker (2020b). American Firms Foresee a Huge Negative Impact of the Coronavirus," macroblog, Federal Reserve Bank of Atlanta, 23 March. 
[6] Armantier, O., W. Bruine de Bruin, W. van der Klaauw, S. Potter, G. Topa, and B. Zafar (2013). Measuring Inflation Expectations. Annual Review of Economics 5, pp. 273-301.

[7] Armantier, O., W. van der Klaauw, G. Topa, and B. Zafar (2016). The Price is Right: Updating Inflation Expectations in a Randomized Price Information Experiment. Review of Economics and Statistics, 98(3), pp. 503-523.

[8] Armantier, O., G. Koşar, R. Pomerantz, D. Skandalis, K. Smith, G. Topa, W. van de Klaauw (2020). How Economic Crises Affect Inflation Beliefs: Evidence from the COVID-19 Pandemic. Federal Reserve Bank of New York Staff Report No. 949.

[9] Balleer, A., S. Link, M. Menkhoff, and P. Zorn (2020). Demand or Supply? Price Adjustment during the COVID-19 Pandemic. Institute of Labor Economics DP No. 13568.

[10] Barrero, J. M., N. Bloom, and S. J. Davis (2020). COVID-19 is Also a Reallocation Shock. NBER Working Paper No. 27137.

[11] Bartik, A. W., M. Bertrand, Z. B. Cullen, E. L. Glaeser, M. Luca, and C. Stanton (2020). The Impact of COVID-19 on Small Business Outcomes and Expectations. Harvard Business School Working Paper 20-102.

[12] Bils, M. and P. Klenlow (2004). Some Evidence on the Importance of Sticky Prices. Journal of Political Economy, 112, pp. 947-985.

[13] Binder, C. (2020a). Coronavirus Fears and Macroeconomic Expectations. Review of Economics and Statistics, 102(4), pp. 721-730.

[14] Binder, C. (2020b). Long-Run Inflation Expectations in the Shrinking Upper Tail. Economics Letters, 186(108867).

[15] Bloom, N., R. Fletcher, and E. Yeh (2020). Forthcoming work using the Stanford-Stripe Survey. For slides see: https:/ / siepr.stanford.edu/sites/default/files/Nick\%20Bloom\%20slides.pdf

[16] Brave, S., A. Butters, and D. Kelley (2019). A New "Big Data” Index of U.S. Economic Activity. Federal Reserve Bank of Chicago Economic Perspectives 43 (1), pp. 1-30.

[17] Brinca, P., J. B. Duarte, and M.F. e Castro (2020). Measuring Labor Supply and Demand Shocks during COVID-19. St. Louis Federal Reserve Working Paper 2020-11D.

[18] Bryan, M., B. Meyer, and N. Parker (2015). The Inflation Expectations of Firms: What Do They Look Like, Are They Accurate, and Do They Matter? Federal Reserve Bank of Atlanta Working Paper, 2014-27a. 
[19] Cajner, T., L. D. Crane, R. A. Decker, J. Grigsby, A. Hamins-Puertolas, E. Hurst, C. Kurz, and A. Yildirmaz (2020). The US Labor Market during the Beginning of the Pandemic Recession. NBER Working Paper No. 27159

[20] Candia, B., O. Coibion, and Y. Gorodnichenko (2020). Communication and the Beliefs of Economic Agents. Conference Draft for Kansas City Federal Reserve's Jackson Hole Symposium, 2020.

[21] Chetty, R., J. N. Friedman, N. Hendren, M. Stepner, and the Opportunity Insights Team (2020). How Did COVID-19 and Stabilization Policies Affect Spending and Employment? A New Real-Time Economic Tracker Based on Private Sector Data. Opportunityinsights.org.

[22] Cochrane, J. (2020). Coronavirus monetary policy. Economics in the Time of COVID-19, a VoxEU.org eBook, CEPR Press, pp. 105-108.

[23] Coibion, O., Y. Gorodnichenko, and S. Kumar (2018). How Do Firms Form Their Expectations? New Survey Evidence. American Economic Review, 108 (9), pp. 2671-2713.

[24] Coibion, O., Y. Gorodnichenko, and M. Weber (2020). Does Policy Communication during COVID-19 Work? Institute of Labor Economics DP No. 13355

[25] Dietrich, A., K. Kuester, G. Muller and R. Schoenle (2020). News and Uncertainty about COVID-19: Survey Evidence and Short-Run Economic Impact. Federal Reserve Bank of Cleveland Working Paper No. 20-12.

[26] Dingel, J. and B. Neiman (2020). How Many Jobs Can be Done at Home? NBER Working Paper No. 26948

[27] Fahlenbrach, R., K. Rageth, and S. R. M (2020). How Valuable is Financial Flexibility when Revenue Stops? Evidence from the COVID-19 Crisis. NBER Working Paper No. 27106

[28] Gagnon, E. and D. Lopez-Salido (2020). Small Price Responses to Large Demand Shocks. Journal of the European Economic Association, 18 (2), pp. 792-828.

[29] Guerrieri, V., G. Lorenzoni, L. Straub, and I. Werning (2020). Macroeconomic Implications of COVID-19: Can Negative Supply Shocks Cause Demand Shortages? NBER Working Paper No. 26918

[30] Hassan, T.A., S. Hollander, L. van Lent, and A. Tahoun (2020). Firm-Level Exposure to Epidemic Diseases: Covid-19, SARS, and H1N1. Working paper.

[31] Kahneman, D., J.L. Knetsch and R. Thaler (1986). Fairness as a Constraint on Profit Seeking: Entitlements in the Market. American Economic Review, 76 (4), pp. 728-741.

[32] Kamdar, R. (2019). The Inattentive Consumer: Sentiment and Expectations. Working Paper. 
[33] Kharas, H. and A. Triggs (2020). The Triple Economic Shock of COVID-19 and Priorities for an Emergency G-20 Leaders Meeting. Brookings Blog. March 17, 2020.

[34] Klenow, P. and O. Kryvtsov (2008). State-Dependent or Time-Dependent Pricing: Does it Matter for Recent U.S. Inflation? Quarterly Journal of Economics, 123, pp. 863-904.

[35] Li, H. and X.S. Sheng (2020). Dating COVID-Induced Recession in the U.S. Forthcoming in Applied Economics Letters

[36] Manski, C. F. (2004). Measuring Expectations. Econometrica, 72(5), pp. 1329-1376.

[37] Meyer, B.H., R. McCord, and S.R. Waddell. (2020). The CFO Survey and Firms' Expectations for the Path Forward. The CFO Survey, Research \& Commentary Note, July 8, 2020.

[38] Meyer, B. H., N. Parker, and X.S. Sheng (2020). Firm Inflation Expectations and Uncertainty. Forthcoming Federal Reserve Bank of Atlanta Working Paper.

[39] Portes, J. (2020). The Lasting Scars of the COVID-19 Crisis: Channels and Impacts. VoxEu.org, June 1, 2020.

[40] Ramelli, S. and A. F. Wagner (2020). Feverish Stock Price Reactions to COVID-19. Swiss Finance Institute Research Paper.

[41] Sbordone, A.M. (2005). Do Expected Future Marginal Costs Drive Inflation Dynamics? Journal of Monetary Economics, 52, pp. 1183-1197.

[42] Shapiro, A. (2020). A Simple Framework to Monitor Inflation. Federal Reserve Bank of San Francisco Working Paper 2020-29. 


\section{Appendix A Business inflation expectations survey questions}

\section{A.1 BIE core monthly questions}

Question: How do your current SALES LEVELS compare with sales levels during what you consider to be "normal"times?

Response options:

o Much less than normal

o Somewhat less than normal

o About normal

o Somewhat greater than normal

o Much greater than normal

Question: How do your current PROFIT MARGINS compare with "normal" times? Response options:

o Unit costs down (less than $-1 \%$ )

o Unit costs about unchanged (-1\% to $1 \%)$

o Unit costs up somewhat (1.1\% to $3 \%$ )

o Unit costs up significantly ( $3.1 \%$ to $5 \%$ )

o Unit costs up very significantly (more than $5 \%$ ) 
Question: Projecting ahead, to the best of your ability, please assign a percent likelihood to the following changes to UNIT COSTS over the next twelve months. (Values should sum to 100\%) For example, if you think each of these is equally likely, you might answer $20 \%$ for each:

$20 \%$ Unit costs down (less than $-1 \%$ )

$20 \%$ Unit costs about unchanged (-1\% to $1 \%)$

$20 \%$ Unit costs up somewhat $(1.1 \%$ to $3 \%)$

$20 \%$ Unit costs up significantly (3.1\% to $5 \%)$

$20 \%$ Unit costs up very significantly (more than $5 \%$ )

Response options:

$\square \%$ Unit costs down (less than $-1 \%$ )

$\square \%$ Unit costs about unchanged (-1\% to $1 \%$ )

$\square \%$ Unit costs up somewhat (1.1\% to 3\%)

$\square \%$ Unit costs up significantly (3.1\% to $5 \%$ )

$\square \%$ Unit costs up very significantly (more than 5\%)

\section{A.2 BIE core quarterly questions}

Question: Projecting ahead, to the best of your ability, please assign a percent likelihood to the following changes to UNIT COSTS per year, over the next five to 10 years. (Values should sum to $100 \%$ )

\section{Response options:}

$\square \%$ Unit costs down (less than $-1 \%$ )

$\square \%$ Unit costs about unchanged (-1\% to $1 \%)$

$\square \%$ Unit costs up somewhat $(1.1 \%$ to $3 \%)$

$\square \%$ Unit costs up significantly (3.1\% to $5 \%)$

$\square \%$ Unit costs up very significantly (more than $5 \%$ )

Question: By roughly what percent are your firm's sales levels ABOVE "normal"? Response options:

Percent 
Question: By roughly what percent are your firm's sales levels BELOW "normal"?

Response options:

Percent

Question: You indicated that your sales levels are "about normal." By roughly what percent are your firm's sales levels above/below "normal", if at all?

Response options:

Above/Below/Neither

Percent

\section{A.3 BIE special questions}

Question: On a scale from 1 to 5, with 1 being "no disruption," how would you assess the level of disruption resulting from the recent outbreak of the coronavirus when it comes to the items listed below?

Response options:

\begin{tabular}{l|c|c|c|c|c|c} 
& 1 - No disruption & 2 & $\begin{array}{l}3 \text { - Moderate dis- } \\
\text { ruption }\end{array}$ & 4 & $\begin{array}{l}5 \text { - Severe disrup- } \\
\text { tion }\end{array}$ & Too soon to tell \\
\hline business operations & 0 & 0 & 0 & 0 & 0 & 0 \\
\hline sales activity & 0 & 0 & 0 & 0 & 0 & 0 \\
\hline
\end{tabular}

Question: With regard to your supplies and/or supply chains, how would you assess the level of negative disruption, if any, resulting from COVID-19 (coronavirus).

Response options:

o No negative disruption

o Some negative disruption

o Significant negative disruption

o Severe negative disruption

o N/A 
Question: Do you expect the price of the product/product line or service responsible for the largest share of your revenue to increase, remain the same, or decrease over the next 6 months? Response options:

o Increase

o Remain the same

o Decrease

Question: By roughly what percentage do you expect the price of the product/product line or service responsible for the largest share of your revenue to increase over the next $\mathbf{6}$ months?

Response options:

Question: What is your best guess (in number of months) for when you will be able to return to normal business operations?

Response options:

$\square$ months

Question: Approximately what share of your workforce performs routine, manual tasks that do not require a college degree or specialized training, commonly referred to as "low-skilled" labor? Response options:

Question: Since the onset of the COVID-19 pandemic (March 1, 2020), approximately what percentage of your low-skilled workforce has seen increases, decreases, and no change in their wages? Values should sum to 100.

Response options:

$\square \%$ Increase in wages

$\square \%$ No change in wages

$\square \%$ Decrease in wages 
Question: From now until the end of 2020, approximately what percentage of your low-skilled workforce do you anticipate will see increases, decreases, and no change in their wages?

Values should sum to 100 .

Response options:

$\square \%$ Increase in wages

$\square \%$ No change in wages

$\square \%$ Decrease in wages

Question: Approximately what share of your workforce performs non-routine, creative tasks and is college-educated (or highly trained), commonly referred to as "high-skilled" labor?

Response options:

Question: Since the onset of the COVID-19 pandemic (March 1, 2020), approximately what percentage of your high-skilled workforce has seen increases, decreases, and no change in their wages?

Values should sum to 100 .

Response options:

$\square \%$ Increase in wages

$\square \%$ No change in wages

$\square \%$ Decrease in wages

Question: From now until the end of 2020, approximately what percentage of your high-skilled workforce do you anticipate will see increases, decreases, and no change in their wages? Values should sum to 100 .

\section{Response options:}

$\square \%$ Increase in wages

$\square \%$ No change in wages

$\square \%$ Decrease in wages 


\section{Appendix B Representativeness of the BIE sample}

Table B.1: BIE panel representativeness

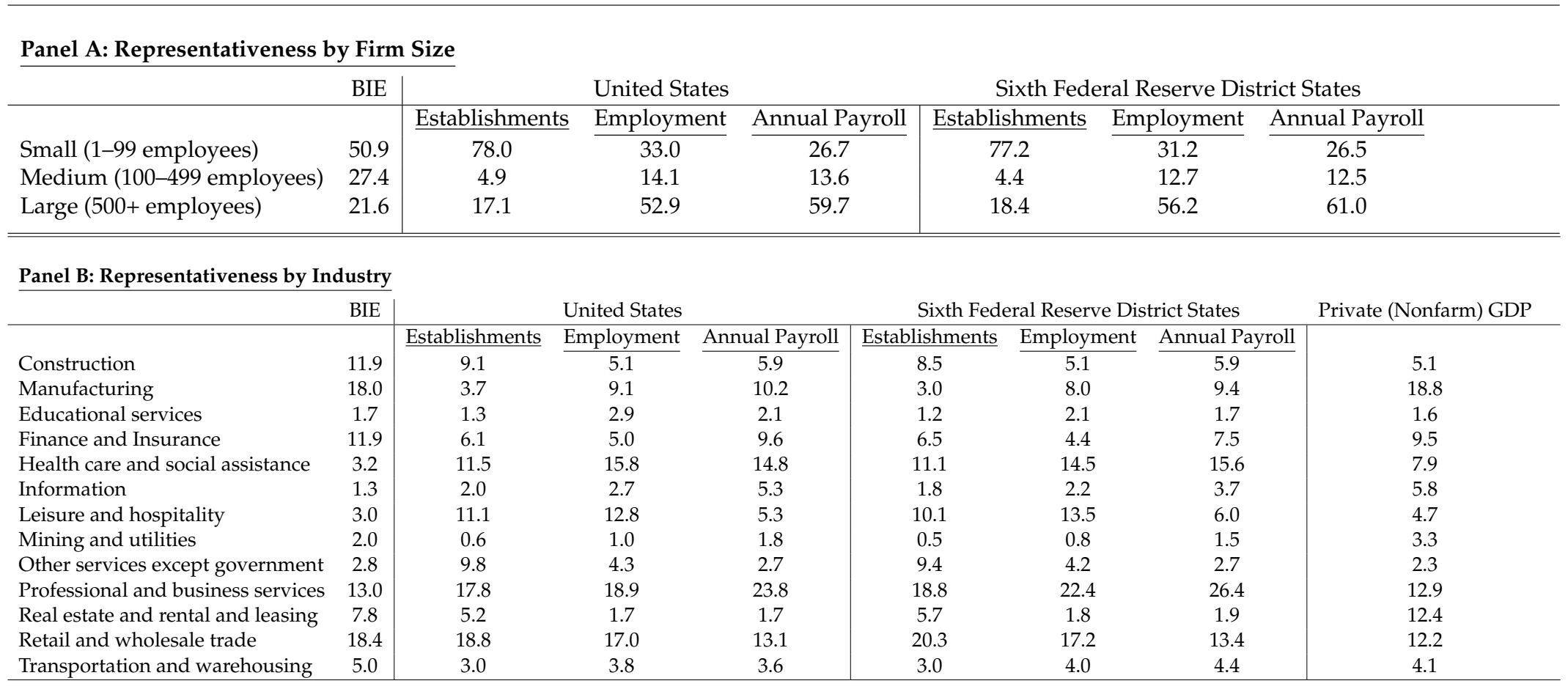

Sources: Census Bureau Statistics of U.S. Businesses 2017; Bureau of Economic Analysis; Federal Reserve Bank of Atlanta's Business Inflation Expectations Survey.

Notes: This table reports the share of U.S. firms. Values are calculated using 2019 nominal values for all private industries excluding agriculture, forestry, fishing, and hunting (NAICS 11). The Atlanta Fed territory covers the Sixth Federal Reserve District, which includes Alabama, Florida, Georgia, and portions of Louisiana, Mississippi, and Tennessee. 


\section{Appendix C Comparison of BIE inflation with price indices and other sources of inflation expectations}

Figure 15: Firms' perceived inflation compared to realized inflation
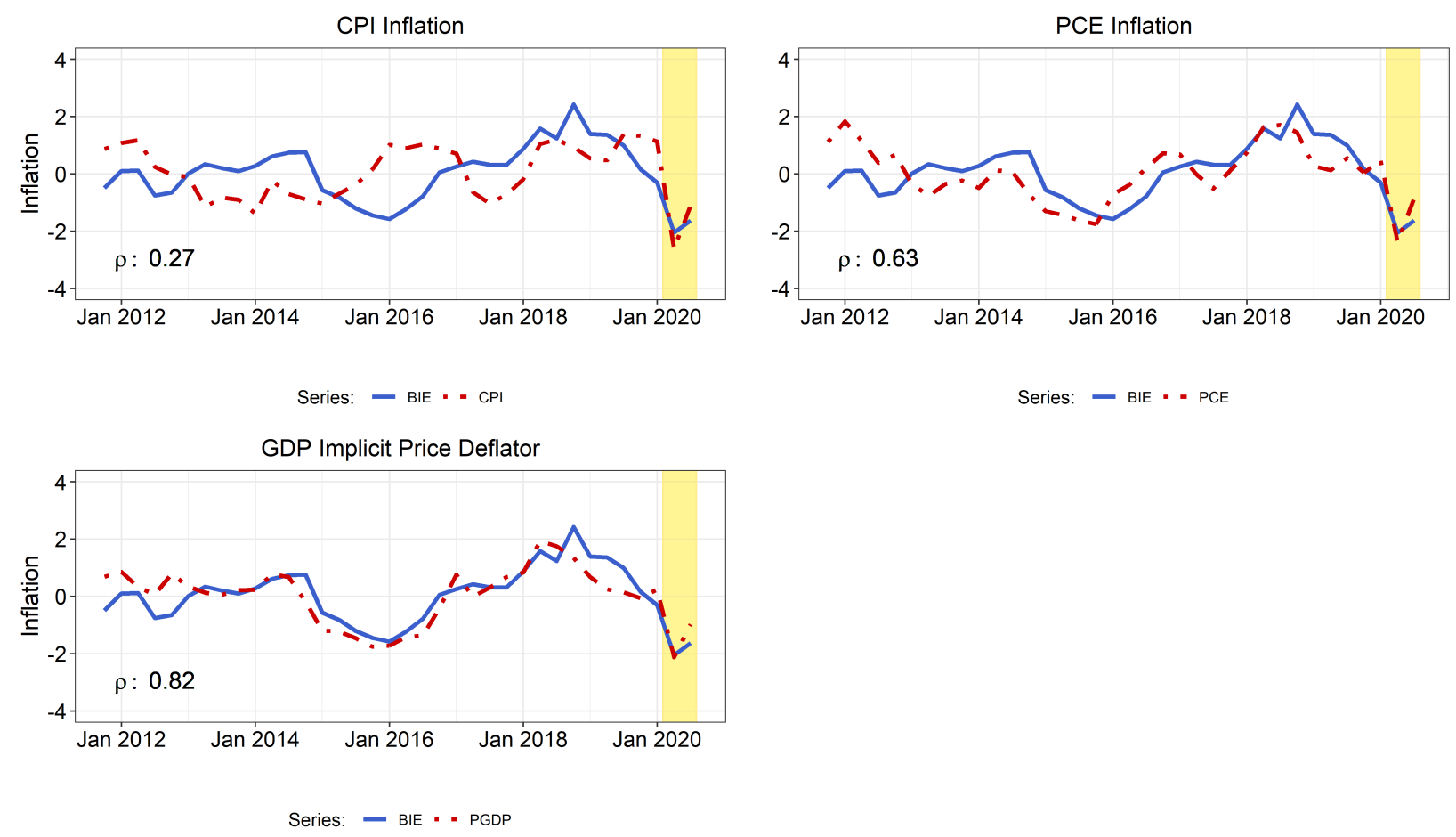

Source: Federal Reserve Bank of Atlanta's Business Inflation Expectations Survey and U.S. Bureau of Economic Analysis

Note: The GDP implicit price deflator is calculated as the 4-quarter growth rate. All of the time-series are standardized and aggregated to the quarterly frequency. The correlation between the time-series is given by $\rho$. 
Figure 16: Comparison of expected 1-year inflation of firms, professional forecasters and households
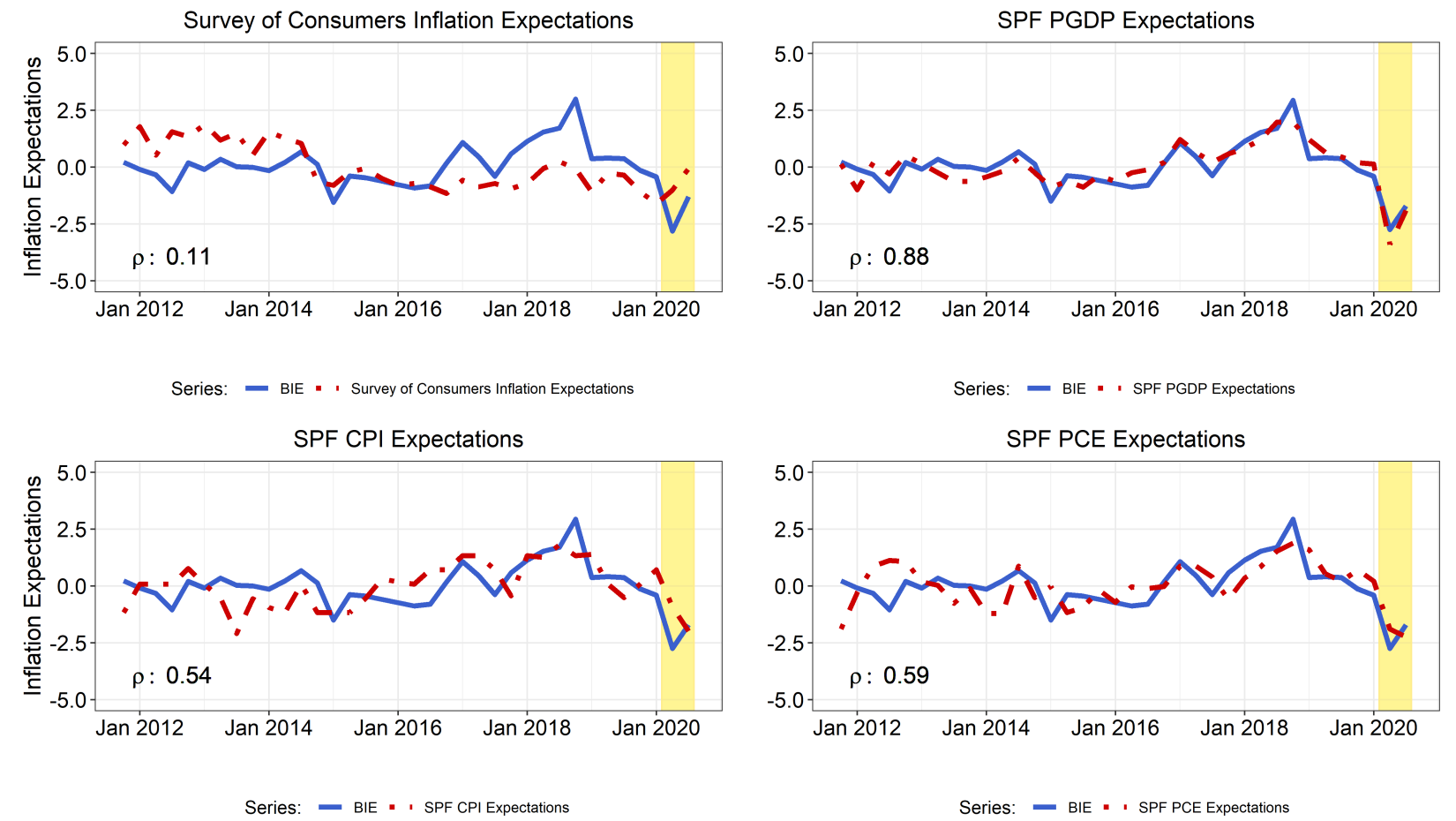

Source: Federal Reserve Bank of Atlanta's Business Inflation Expectations Survey and Federal Reserve Bank of Philadelphia's Survey of Professional Forecasters

Note: The professional forecaster expectations are the median forecast and each time-series is standardized and aggregated to the quarterly frequency. The correlation between the time-series is given by $\rho$. 
Figure 17: Perceived inflation of firms by sector

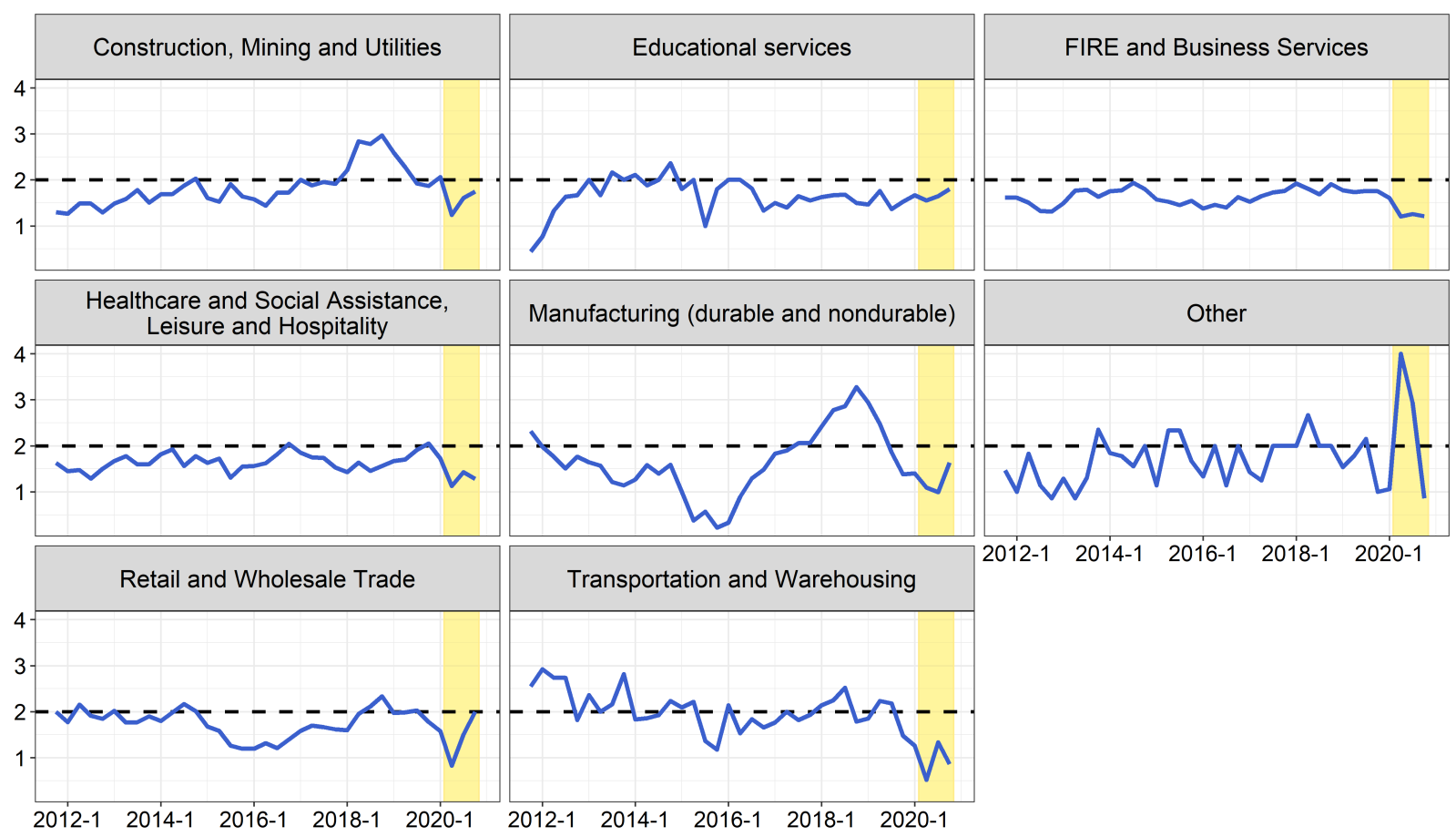

Source: Federal Reserve Bank of Atlanta's Business Inflation Expectations Survey. 
Figure 18: Expected 1-year inflation of firms by sector

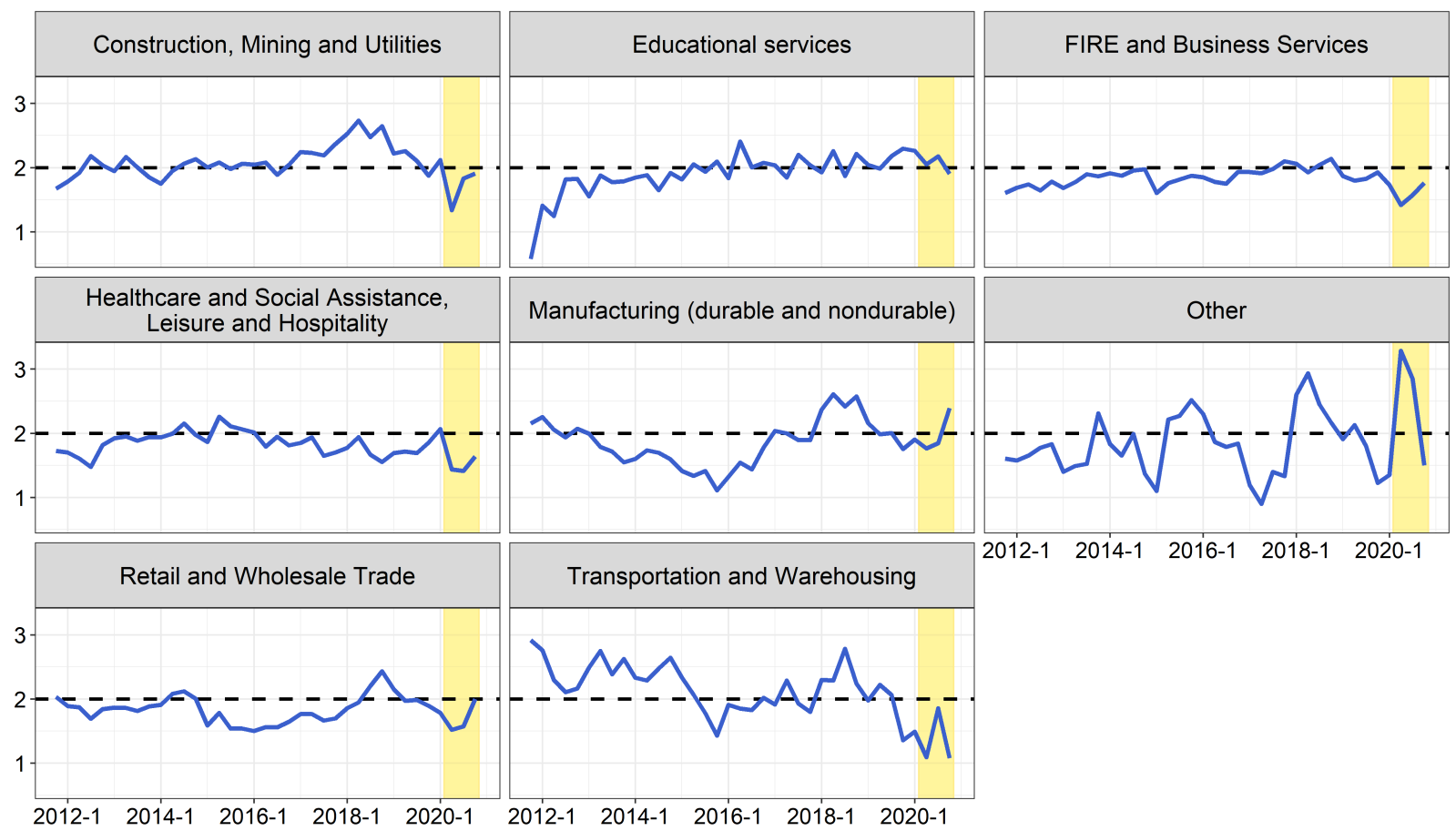

Source: Federal Reserve Bank of Atlanta's Business Inflation Expectations Survey. 
Figure 19: Expected 1-year inflation of firms from the BIE and Survey of Business Uncertainty (SBU)
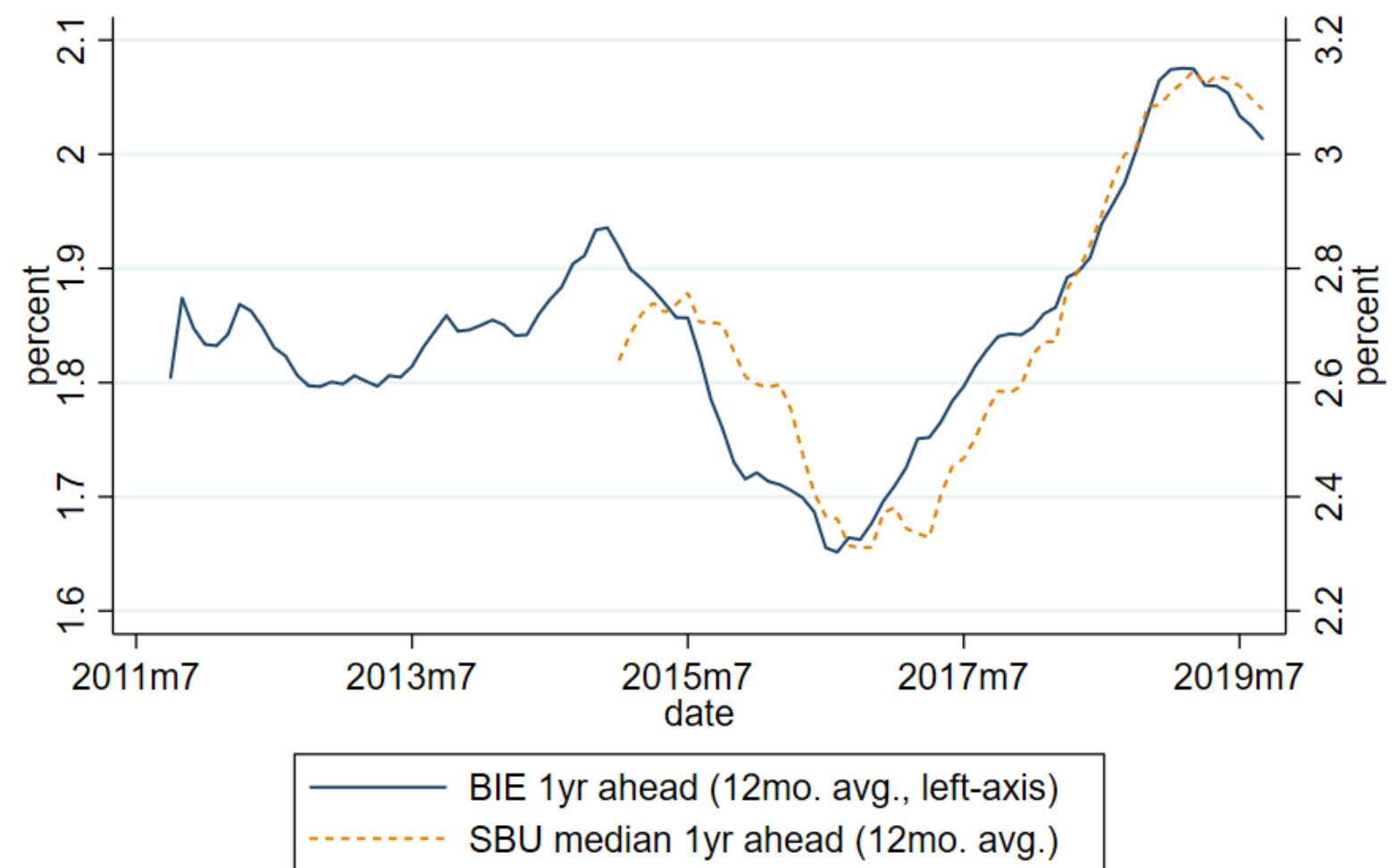

Correlation .93

Source: Federal Reserve Bank of Atlanta's Business Inflation Expectations Survey and Federal Reserve Bank of Atlanta/University of Chicago Booth School of Business/Stanford University's Survey of Business Uncertainty

Note: The specific questions asked in the SBU are: "Looking ahead, from now to 12 months from now, what approximate percentage change in your AVERAGE UNIT COST would you assign to each of the following scenarios?" followed by "Please assign a percentage likelihood to the AVERAGE UNIT COST changes you entered. (Values should sim to 100\%)". The SBU was first fielded during January 2017. 
Figure 20: Expected long-run inflation of firms and professional forecasters
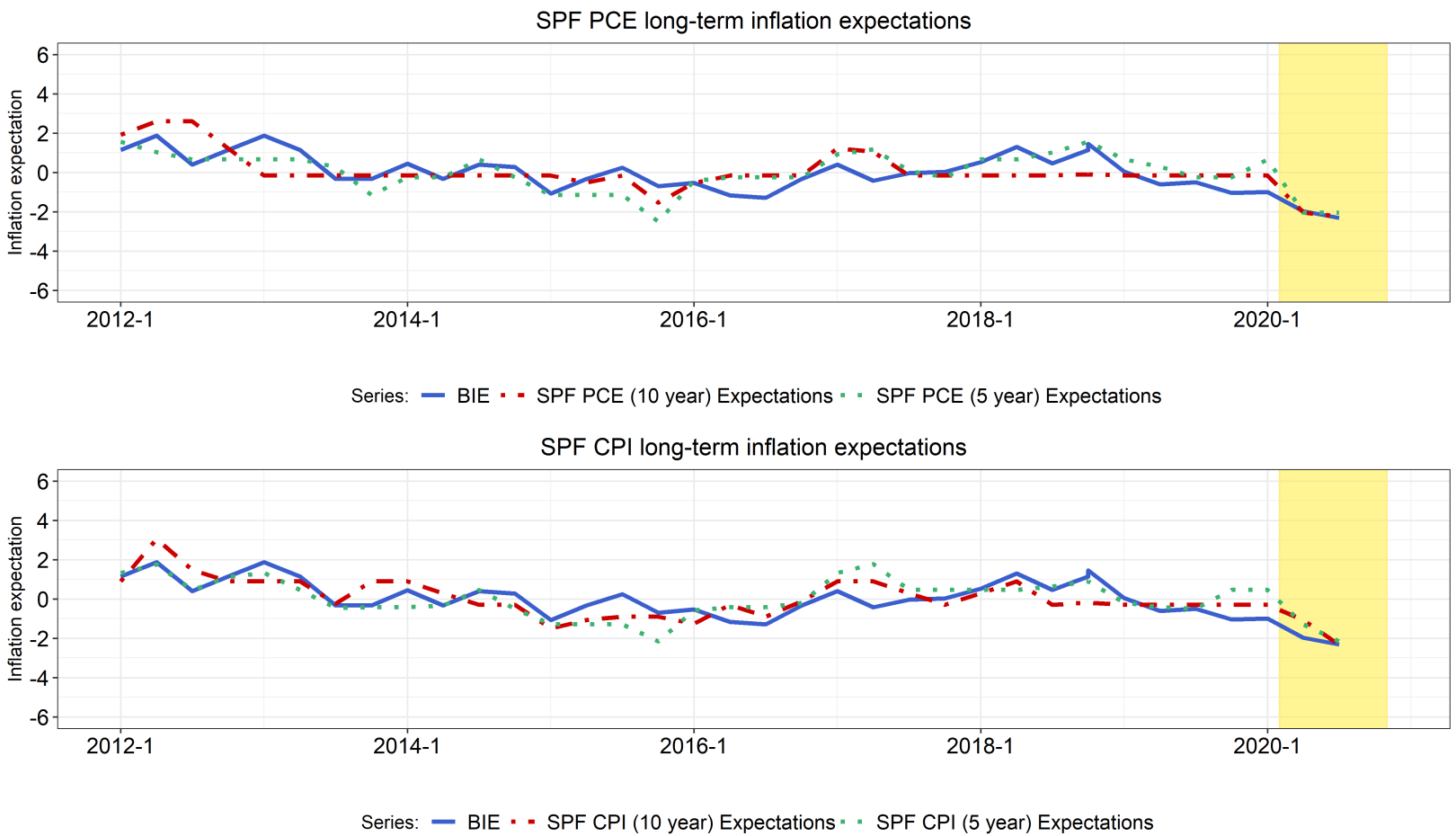

Source: Federal Reserve Bank of Atlanta's Business Inflation Expectations Survey and Federal Reserve Bank of Philadelphia's Survey of Professional Forecasters

Note: The professional forecaster expectations are the median forecast and each time-series is standardized. 


\section{Appendix D Monthly distribution of firms' inflation expectations}

Figure 21: Distribution of short-run inflation expectations

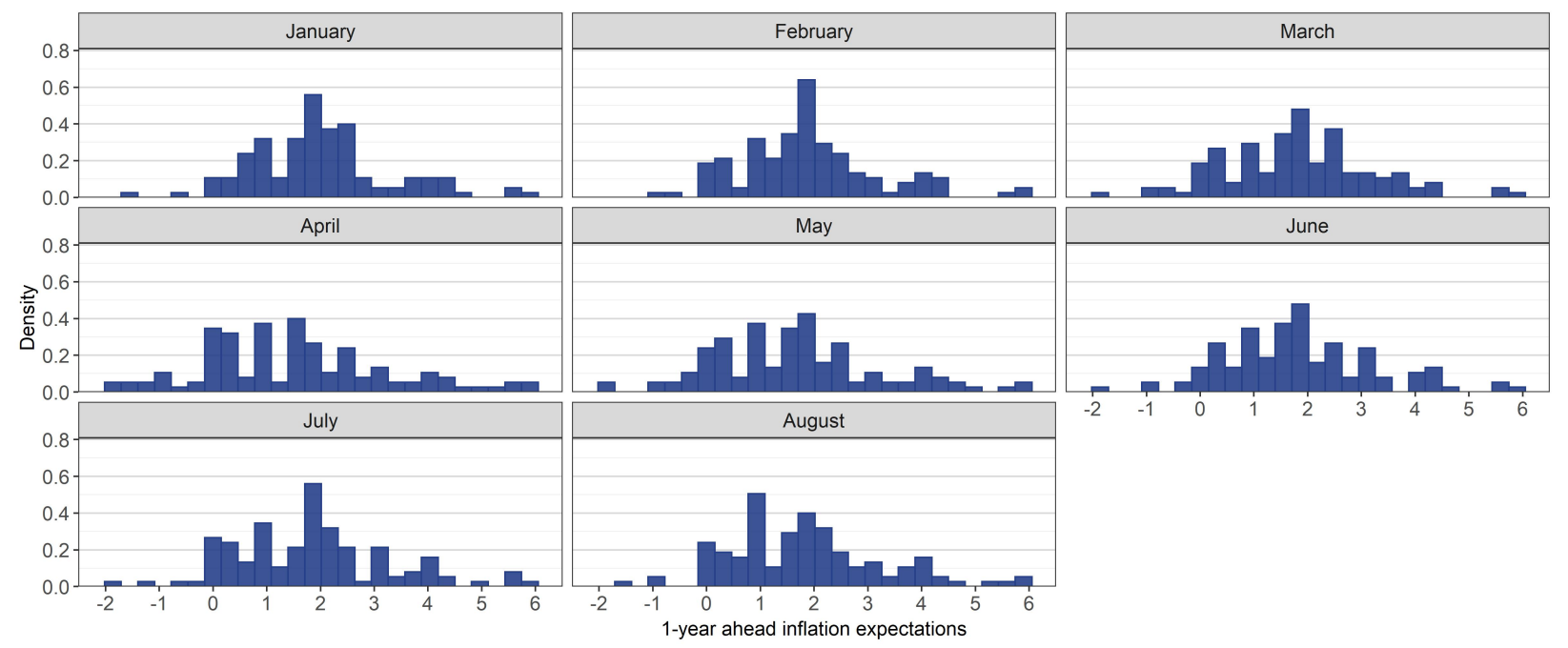

Source: Federal Reserve Bank of Atlanta's Business Inflation Expectations Survey, January to August 2020. Note: The specific question asked is provided in Appendix A. This question is asked to firms on a quarterly basis. 
Figure 22: Distribution of long-run inflation expectations

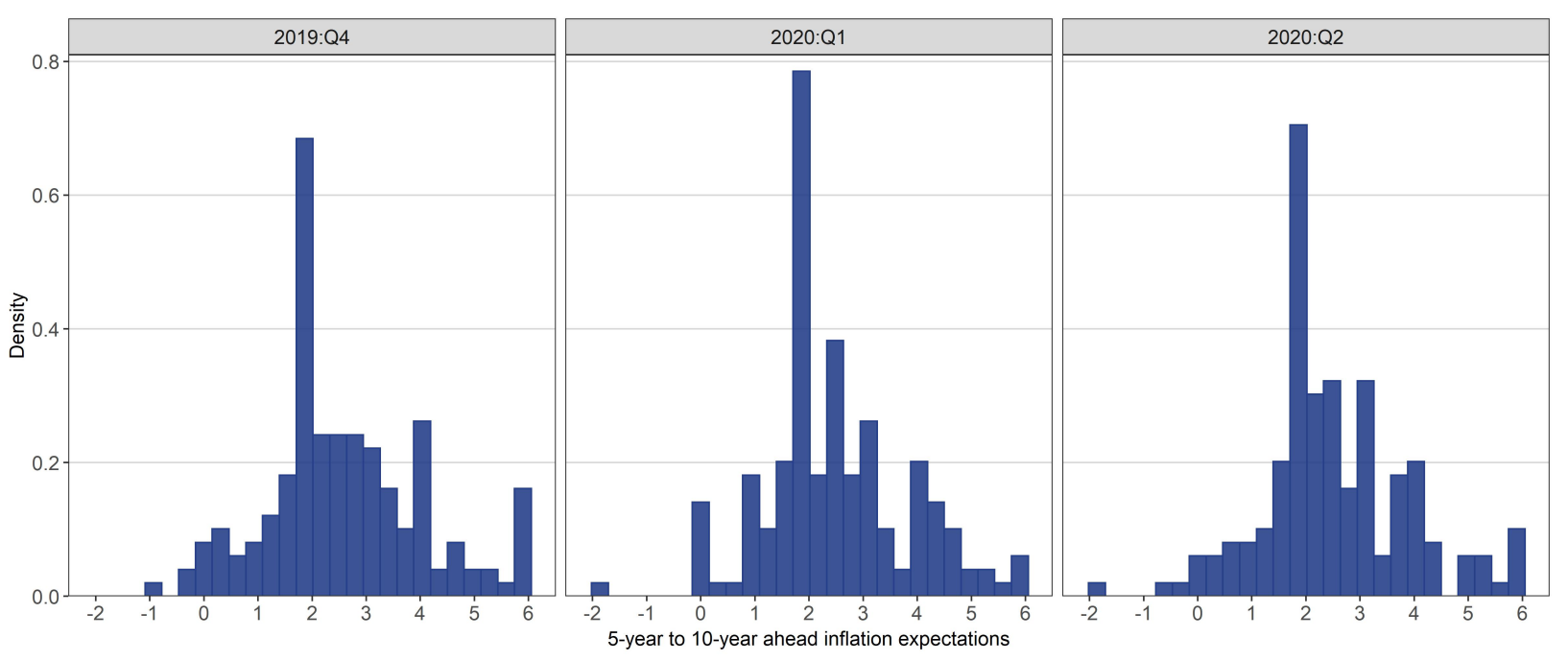

Source: Federal Reserve Bank of Atlanta's Business Inflation Expectations Survey, 2019:Q4 to 2020:Q2. Note: The specific question asked is provided in Appendix A. This question is asked to firms on a quarterly basis. 


\section{Appendix E Influence of inflation and unit costs on pricing}

Figure 23: Sticky price questions from March 2019

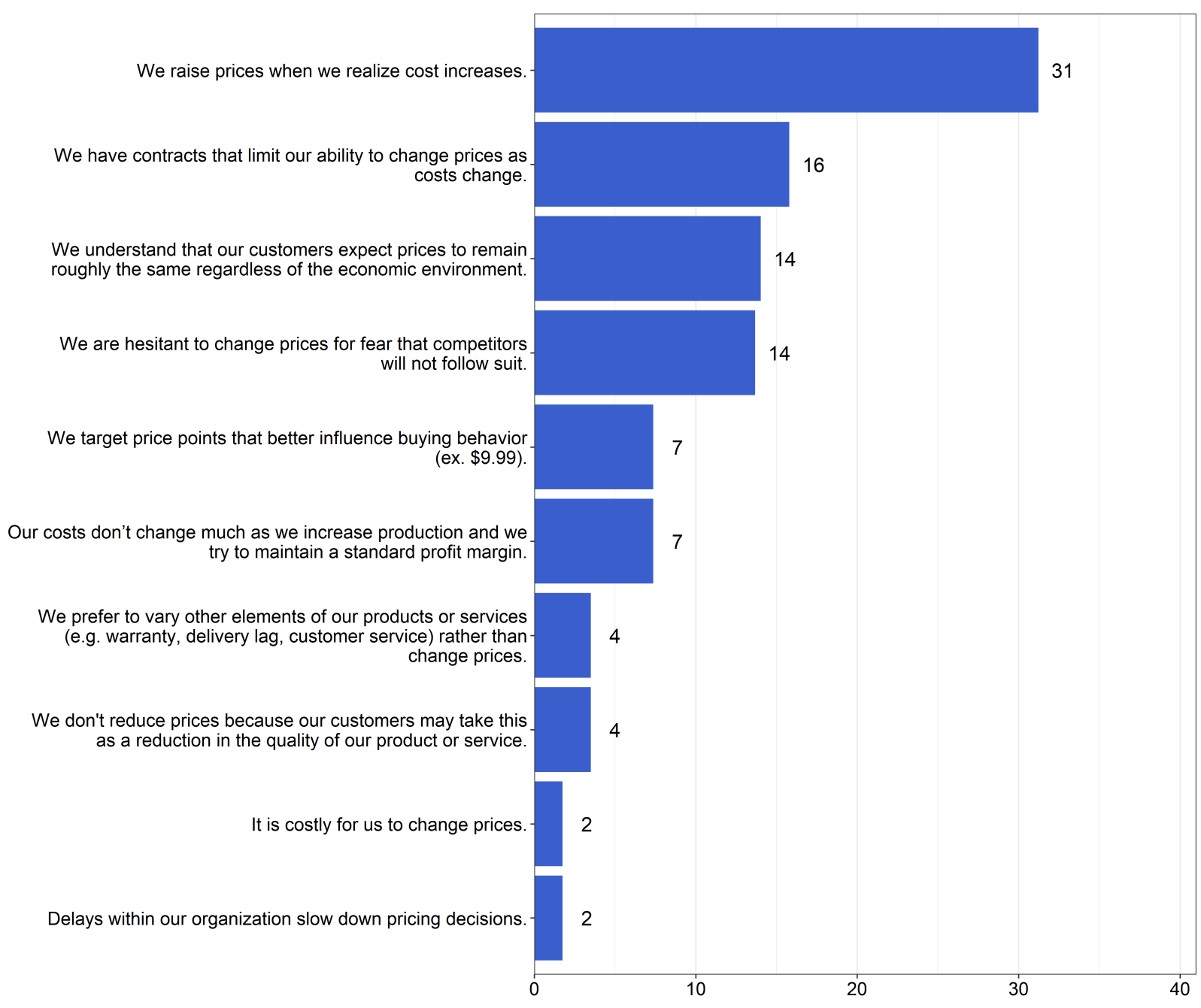

Source: Federal Reserve Bank of Atlanta's Business Inflation Expectations Survey, March 2019. Notes: The histograms are calculated as the share of all responses. 
Figure 24: Importance of aggregate inflation and unit costs on pricing decisions

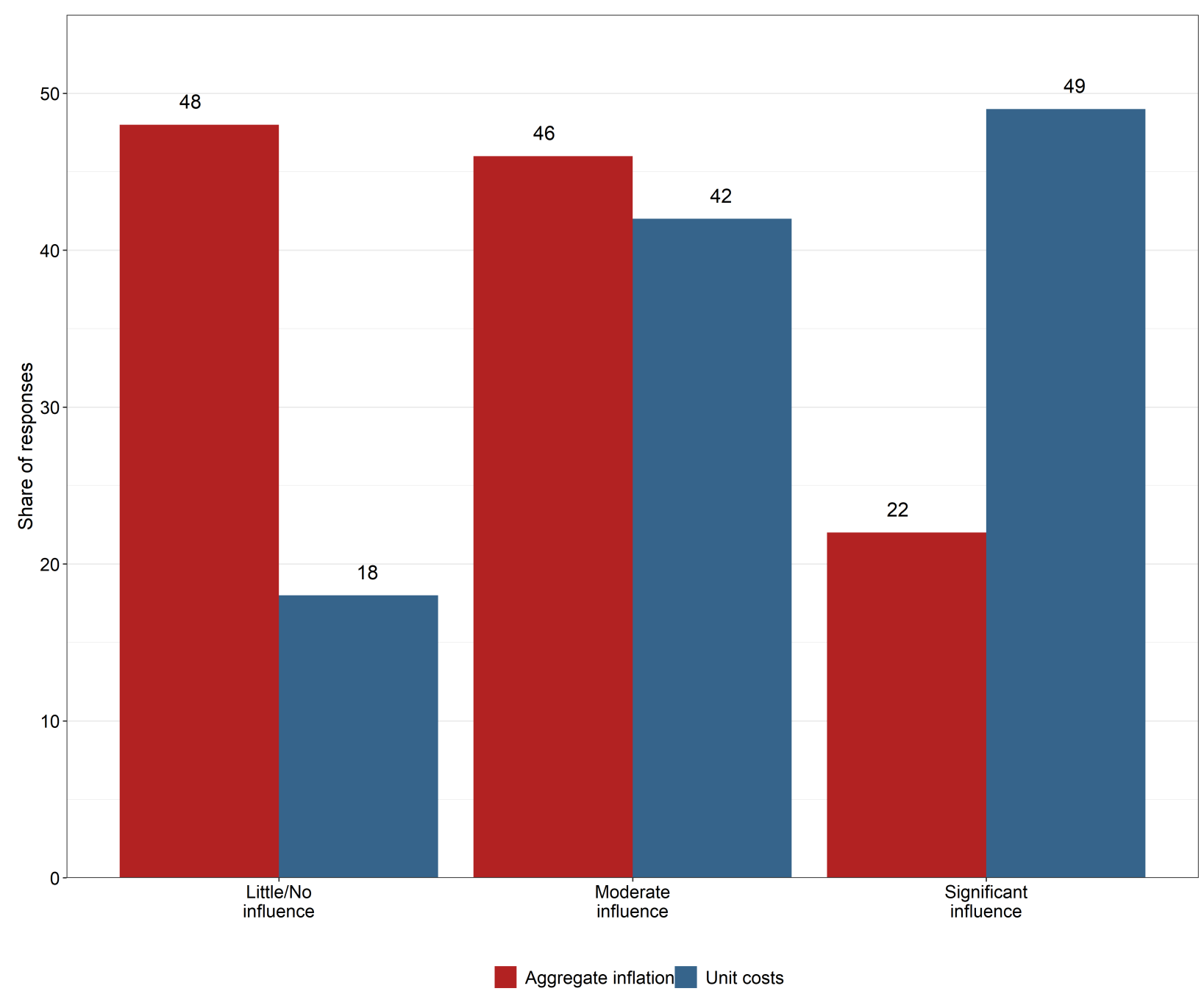

Source: Federal Reserve Bank of Atlanta's Business Inflation Expectations Survey, September 2015.

Notes: For both aggregate inflation and unit costs firms were asked "On a scale from 1 to 5, with 1 being "no influence," please indicate what level of influence, if any, your expectations regarding the economy's overall rate of inflation has on your pricing decisions?" The y-axis is defined by: No influence $=1$; Moderate influence $=2$ or 3; Significant influence $=4$ or 5 . 


\section{Appendix F Firms' biggest challenge over the next year due to COVID- 19}

Figure 25: Expected biggest challenge from September 2020 to September 2021

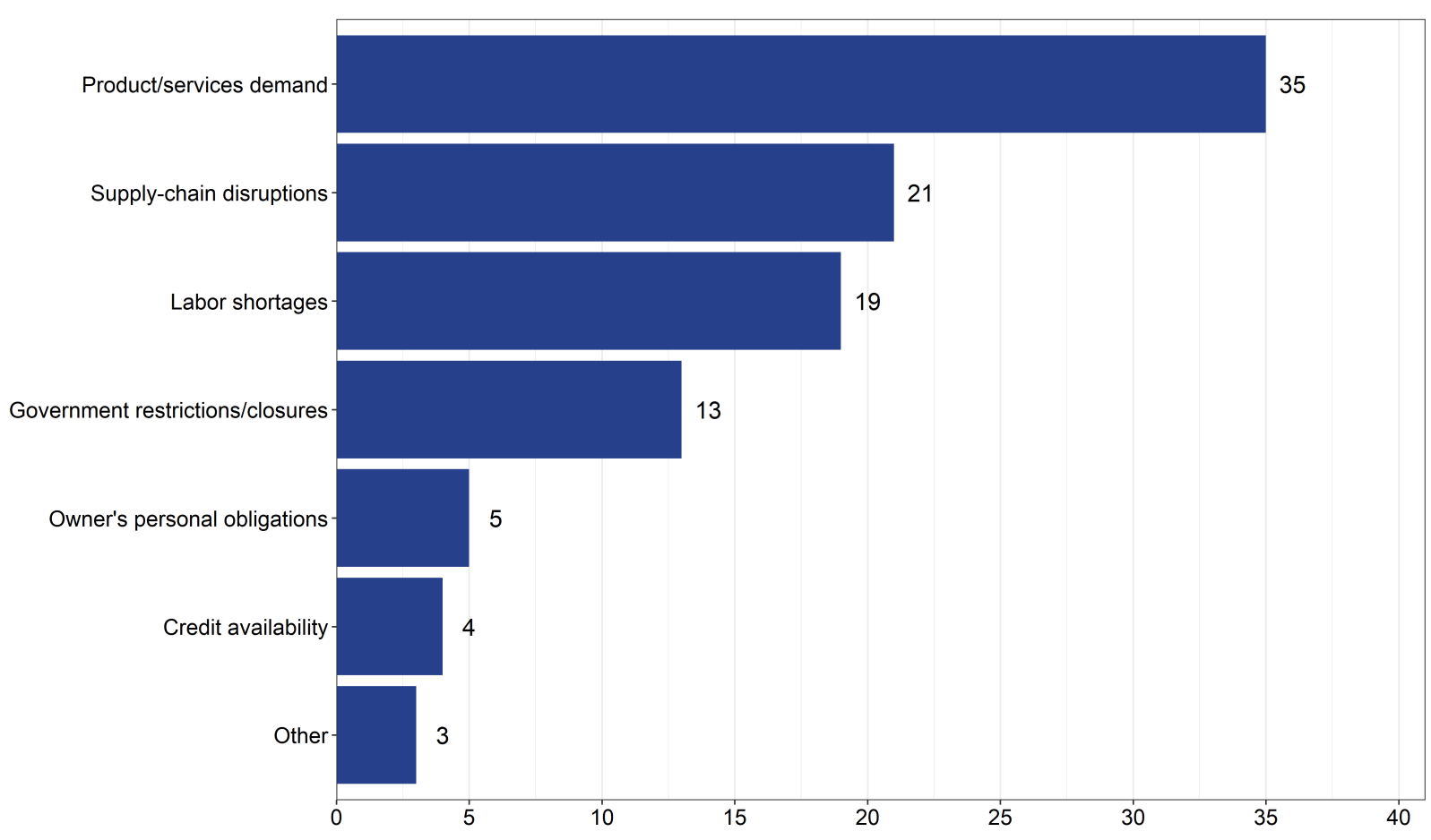

Source: Federal Reserve Bank of Atlanta's Business Inflation Expectations Survey, September 2020.

Notes: The $y$-axis reports the share of firms citing a reason as their biggest expected challenge. The histograms are based on 153 responses to a special question. More precisely, firms were first asked "Over the next 12 months, what challenges do you expect your business will face as a result of COVID-19, if any?" Those who selected anything other than "No significant challenges" were then given a menu of the challenges they selected and asked which of the following would be their biggest challenge.

Approximately 5 percent of firms sampled cited "No significant challenges". 


\section{Appendix G Household "inflation" expectations}

The following wording is taken from the Cleveland Fed's Consumers and COVID-19 survey question about inflation expectations.

Over the next 12 months, do you think that the coronavirus will cause inflation to be higher or lower? Higher/Lower

Depending on the answer (Higher/Lower), we ask respondents to fill in their point estimates according to:

How much [higher/lower] do you expect the rate of to be over the next 12 months because of coronavirus? Please give your best guess.

I expect the rate of inflation to be ___ percentage points [higher/lower] because of coronavirus.

Figure 26: Household's expected impact of COVID-19 on inflation - results

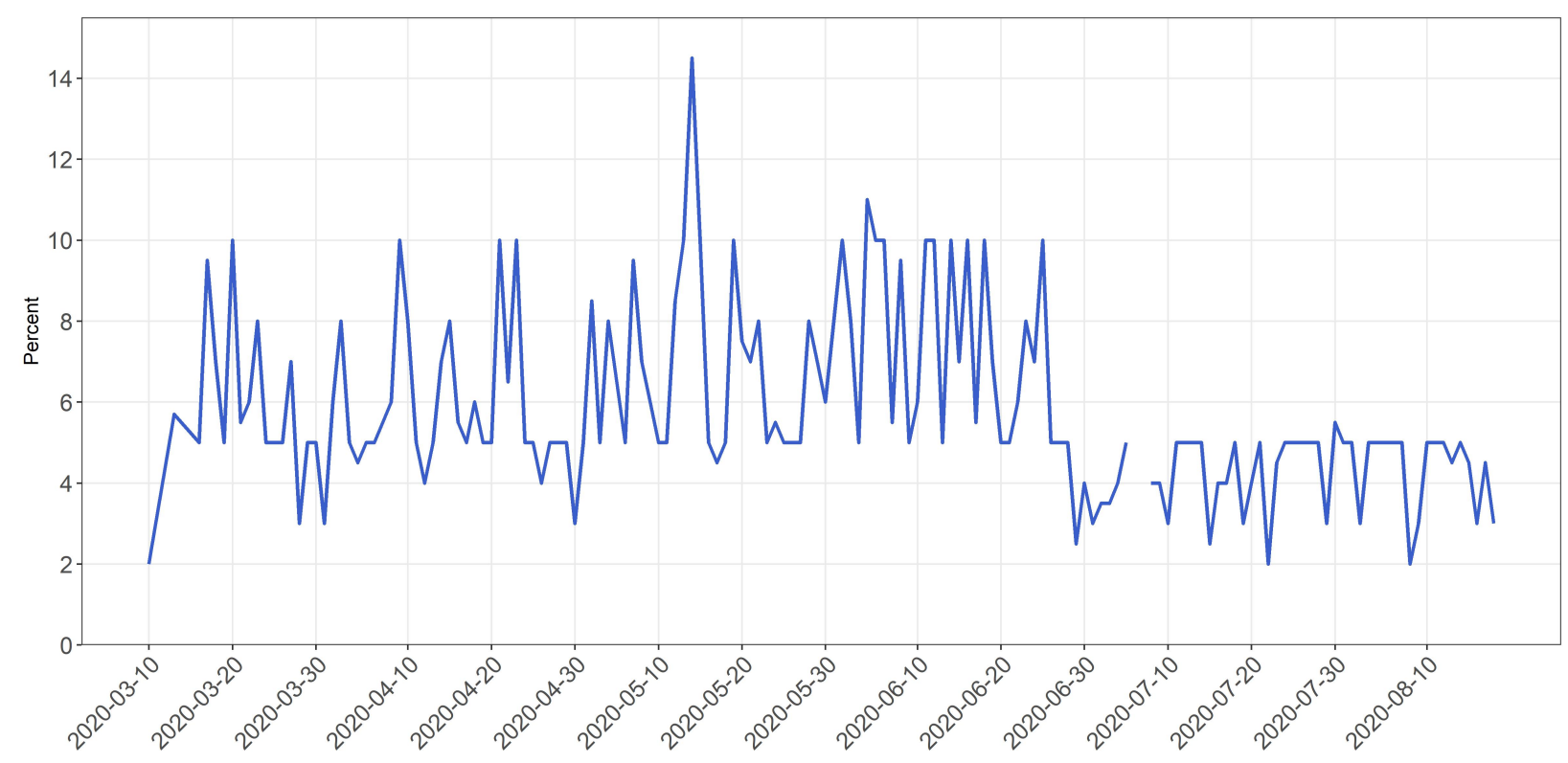

Source: Federal Reserve Bank of Cleveland's Consumers and COVID-19 


\section{Appendix H Evolution of COVID-19 in the Sixth Federal Reserve district vs the U.S.}

Figure 27: Time-Series of COVID-19 Cases and Deaths
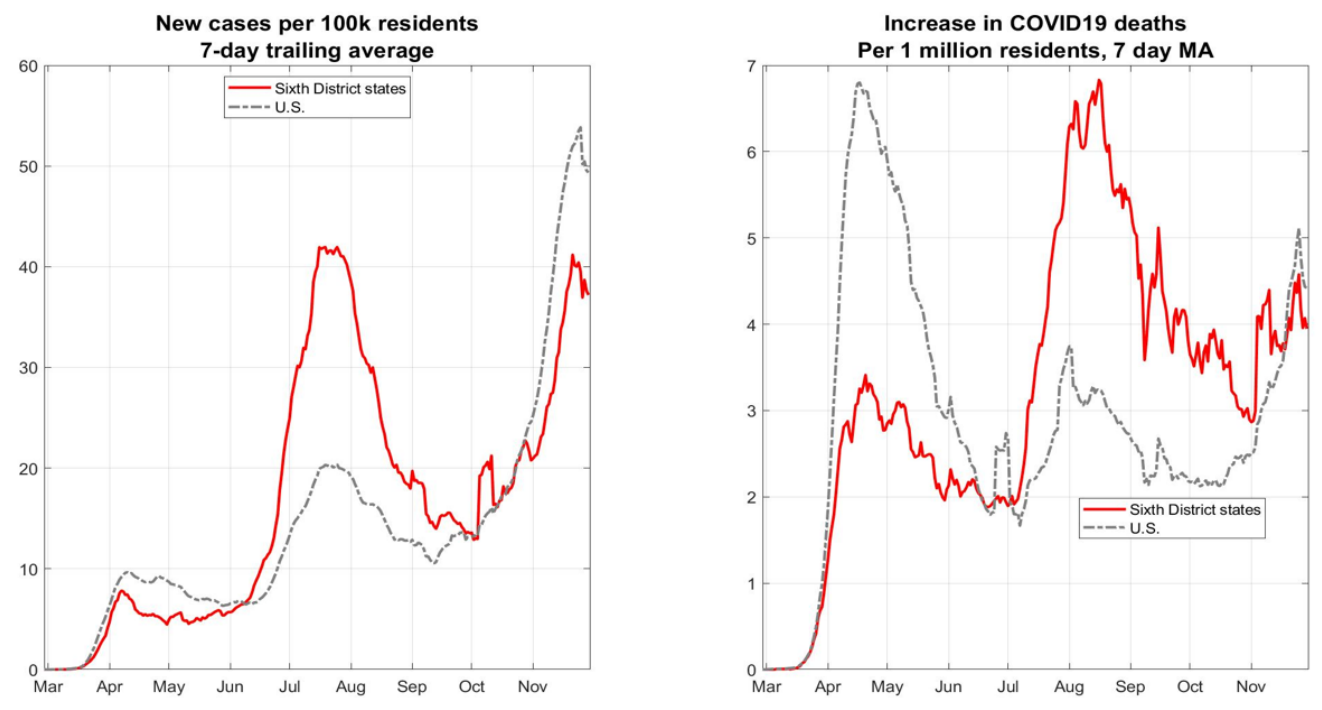

Source: New York Times

Note: The data used is through November $29^{\text {th }}$. 
Figure 28: State-Level Government Response Stringency Index

Oxford State-Level Government Response Stringency Index

Population weighted: $0=$ Minimum, $100=$ Maximum

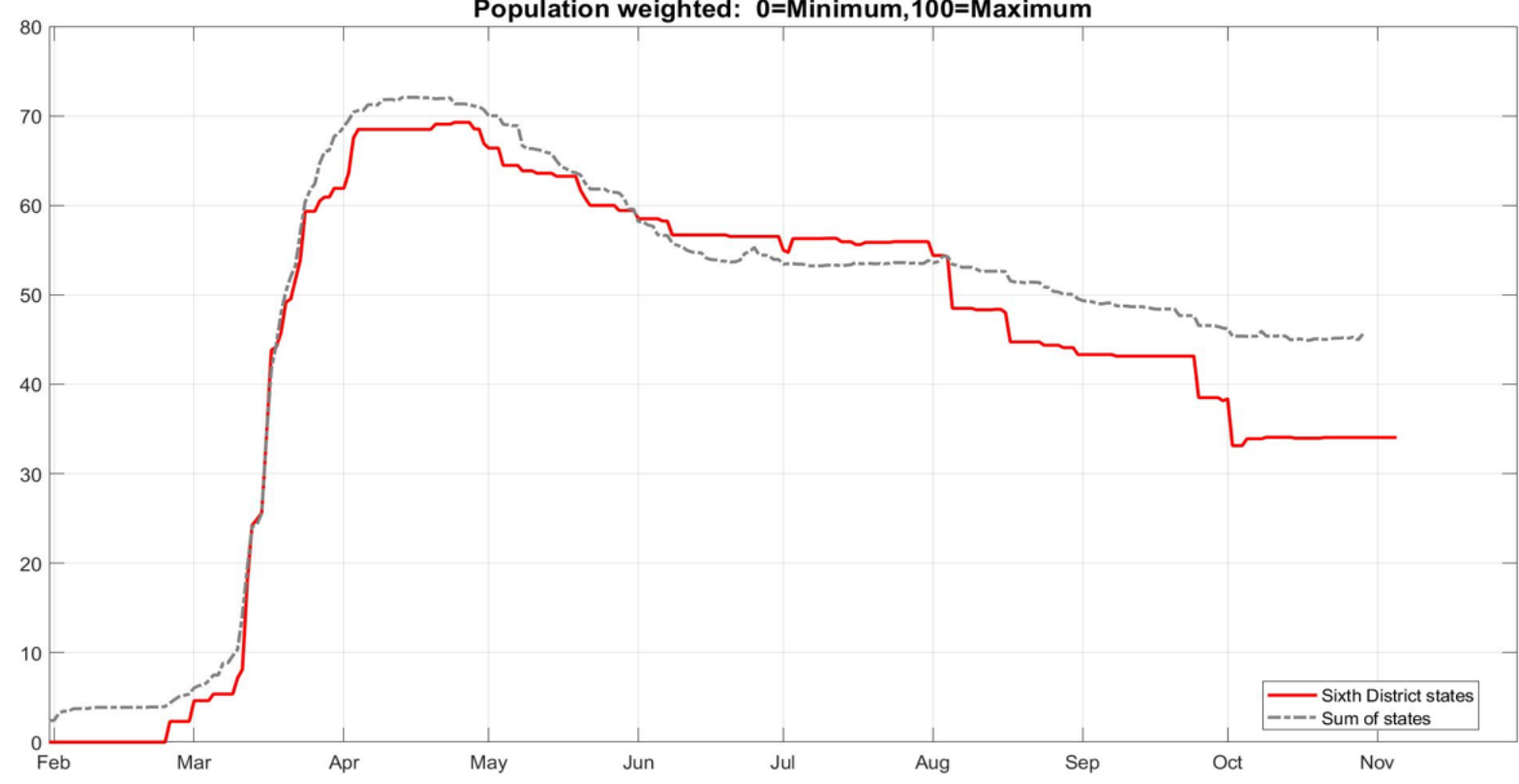

Source: University of Oxford

Note: The minimum possible value is 0 and the maximum is 100 . State population sizes used to combine states. 
Figure 29: Dallas Fed's Mobility and Engagement Index and Open Table Seated Restaurant Diners
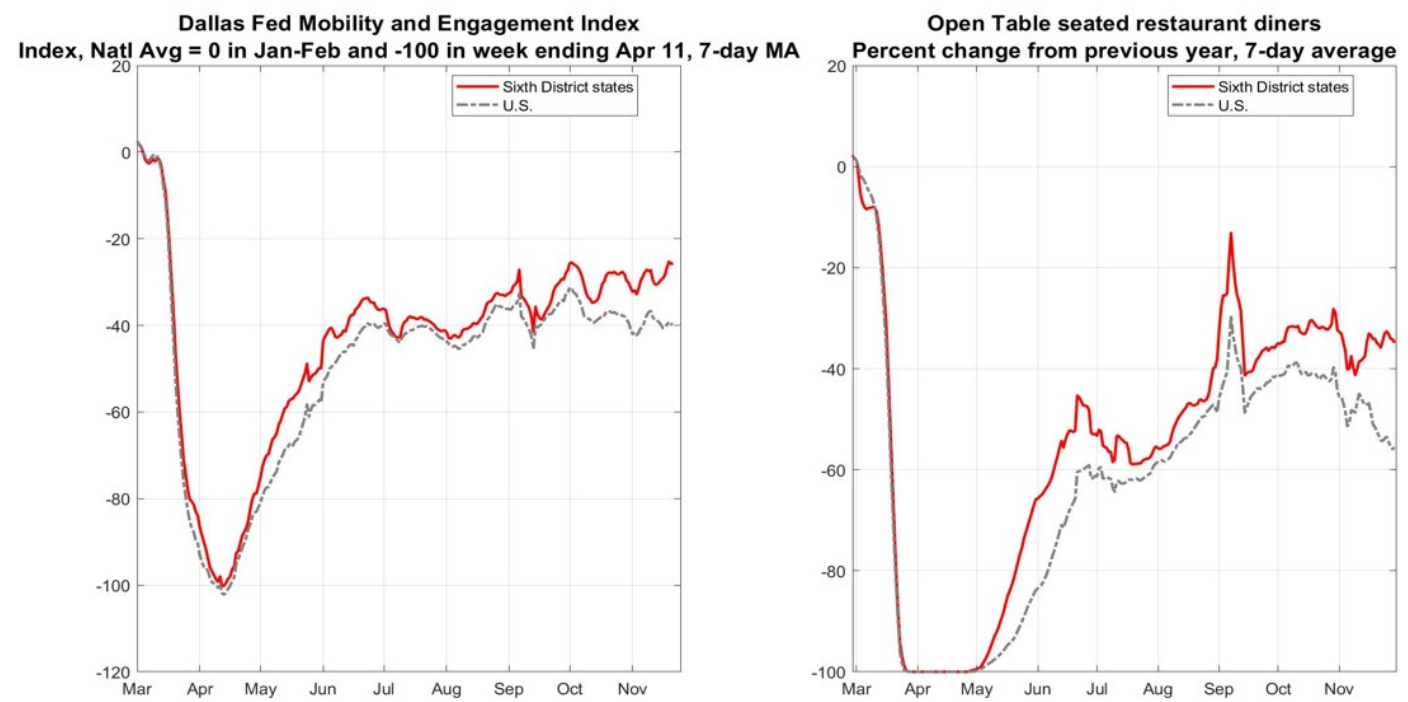

Sources: Federal Reserve Bank of Dallas's Mobility and Engagement Index; Open Table Note: State population sizes are used to aggregate sixth district states in the Dallas Fed figure. 2018 State PCE spending on food services and accommodations used to aggregate sixth district states.

Figure 30: Google Mobility Indices
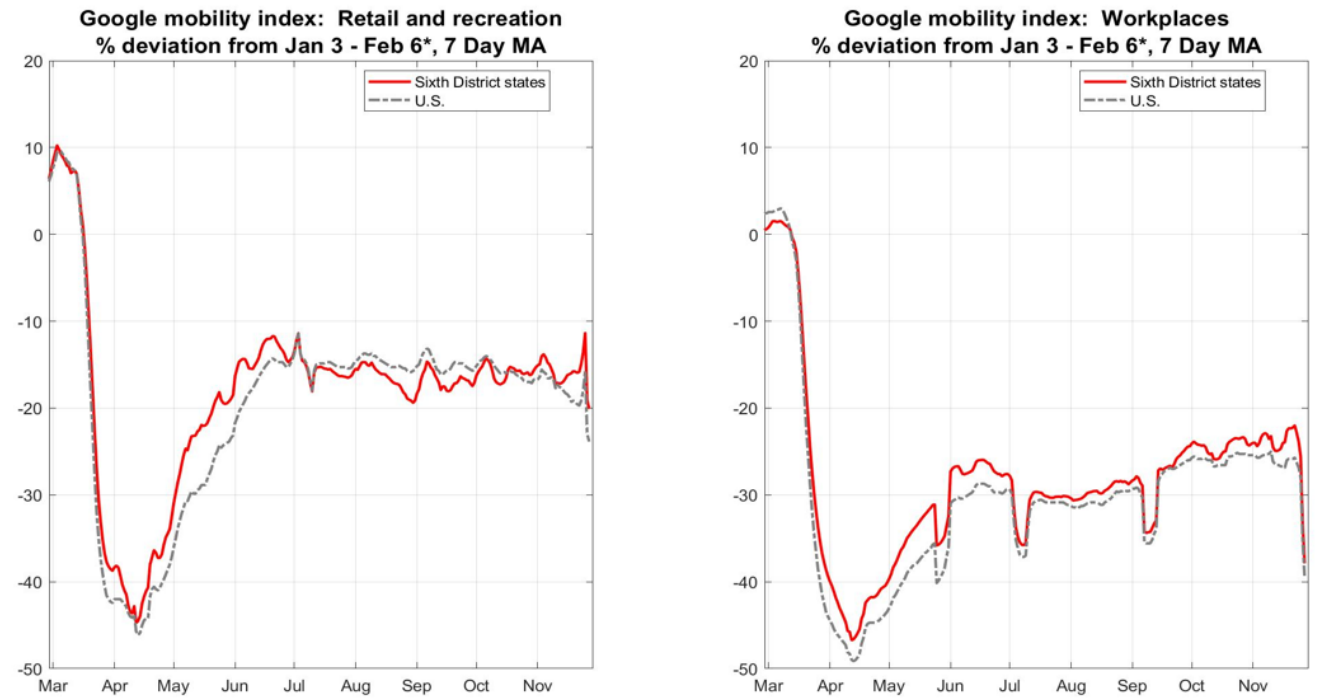

Source: Google COVID-19 Community Mobility Reports.

Notes: Mobility is compared with median mobility on same day of week over January 3 to February 6 period to account for day of the week effects. The data ends November 27. State population sizes are used to combine sixth district state mobility measures. 